\title{
Parameters driving environmental performance of energy storage systems across grid applications
}

Maryam Arbabzadeh*a, Jeremiah X. Johnson ${ }^{\text {a }}$, Gregory A. Keoleian ${ }^{\mathrm{a}}$

\section{- Abstract}

Large-scale energy storage may effectively meet the needs of several grid applications. However, understanding the environmental impact of energy storage for these grid applications is challenging due to diversity in loads, grid mixes, and energy storage systems. Comprehensive sustainability assessments are necessary to yield the best environmental outcomes for grid-scale energy storage systems. To achieve this, we first developed fundamental principles for green energy storage, addressing key issues such as material sustainability, round-trip efficiency, service life, and degradation. In the current study, we couple the principles with a sustainability assessment model to investigate the impact of design and operational parameters on environmental outcomes of utilizing energy storage for grid applications. This model takes into account the service that the energy storage would provide (e.g., bulk energy time-shifting) as well as the energy storage parameters and grid application parameters that influence environmental outcomes. Parameters examined include energy storage round-trip efficiency, degradation, service life, upstream production burden, and heat rates of charging and displaced generation technologies. Environmental sustainability performance is evaluated using a universal set of equations that incorporates all the mentioned parameters. The relationships between these parameters are investigated to determine their influence on environmental performance of energy storage for three grid applications: energy time-shifting, frequency regulation, and power reliability. This model guides the design and operation of new and existing technologies, targeting audiences from energy storage designers to energy storage operators and power utilities.

Keywords: energy storage; environmental outcomes; life cycle emissions; sustainability; design and operational parameters 


\begin{tabular}{|l|l|}
\hline Nomenclature & \\
& energy storage round-trip efficiency \\
& energy storage service life \\
& annual degradation in energy storage round-trip efficiency and capacity \\
& energy storage production burden (storage dependent) \\
& energy storage production burden (power rating dependent) \\
& charging technology upstream emissions factor \\
& charging technology combustion emissions factor \\
& displaced technology upstream emissions factor \\
& displaced technology combustion emissions factor \\
& charging technology heat rate \\
& displaced technology heat rate \\
& energy storage power rating (M W ) \\
& energy storage size (M W h) \\
& number of cycles \\
& study lifetime \\
&
\end{tabular}

\section{Introduction}

The integration of energy storage systems into the power grid may lead to a wide range of environmental impacts [1] [2]. Environmental sustainability assessments can guide both development and deployment of energy storage technologies to achieve better environmental outcomes. M any existing environmental assessments, however, have not systematically evaluated the influence of various parameters on these environmental impacts across grid applications. In this study, we address this gap by developing model equations to explore the key parameters that influence environmental outcomes of integrating energy storage systems. This parametric model shows how environmental impact of energy storage integration may be influenced by energy storage parameters and grid application parameters. Across the full range of parameters, environmental outcomes could be positive or negative. It can be used as a guideline to determine, systematically, when and how to choose storage systems to achieve positive environmental outcomes. 
Several studies have analyzed the environmental implications of energy storage systems [3] [4]. A rgonne National Laboratory conducted life cycle assessments of different battery technologies, examining emissions, energy requirements, water, and solid waste indicators [5]. Their results indicated that lead-acid batteries had the lowest production burden compared to other battery technologies. Chul et al. conducted life cycle analysis of lithium-ion battery electric vehicles from cradle-to-gate [6]. Their results demonstrated that cell manufacturing had the main contribution in upstream greenhouse gas emissions. In a life cycle analysis of batteries, B ossche et al. concluded that the environmental impacts of assembly and production stages could be offset significantly when the collection and recycling of batteries was efficient and performed on a large scale [7]. Hou et al. and Larcher and Tarascon emphasized that the advancements for sustainable energy storage systems depended on the discovery of less expensive and environmentally benign materials [8] [9]. In a life cycle assessment of compressed air energy storage (CAES), Bouman et al. concluded that the design and processing of underground air storage had a large contribution in environmental impacts [10].

Other studies have explored the integration of storage systems and the associated environmental outcomes. A rbabzadeh et al. showed that in an off-grid system, increasing vanadium redox flow battery capacity would have environmental benefits when reducing high wind curtailment [11]. Hiremath et al. showed that it would be misleading to exclude the use stage impacts and neglect the stationary application of battery technologies in an evaluation of their environmental performance, especially when they had different characteristic parameters [12]. They also demonstrated that increasing round-trip efficiency of batteries reduced their life cycle greenhouse gas (GHG) emissions significantly. Poizet and Dolhem emphasized that, besides reducing the consumption of non-renewable materials in rechargeable batteries, managing the batteries during their lifetime would influence their sustainability performance [13].

Other studies have demonstrated the importance of the grid mix [1] [14] [15], presence of renewables [16] [17] [18], and off-peak marginal generation [19] on environmental outcomes from integrating energy storage. Across all of these examples, we see that production, operation, and deployment of energy storage systems within a grid application can impact the environmental outcomes. Although these studies provide valuable insights into the environmental impacts of 
integrating energy storage systems, they do not systematically examine the role of energy storage parameters and grid application parameters in affecting these impacts. Our parametric analysis allows us to provide concrete recommendations which can be tailored to different grid applications and storage technologies, to influence the environmental impacts of integrating energy storage systems.

Each energy storage technology differs in operational parameters, longevity, and materials requirements. Several studies have identified and compared the characteristics of various energy storage systems that need to be evaluated when considering energy storage on the utility scale. These studies demonstrated that key energy storage parameters such as service life, efficiency, capacity, and number of cycles, among others, differed greatly across technologies [8] [20] [21] [22] [23] [24].

Energy storage systems can be utilized for several distinct grid applications such as ancillary services and bulk storage for renewable integration [25] [26]. Each grid application has specific performance requirements that determine which energy storage technologies are suitable to meet the application's performance requirements. Several studies have reviewed technical characteristics of energy storage technologies and identified their potential grid applications, including reports by the Department of Energy and the Sandia National Laboratory [27] [28] [29] [30] [31], and the Electric Power Research Institute [25] [32]. These and other studies [33] - [38] show that the fit of an energy storage system to a specific grid application depends on its match with the performance requirements of the desired application.

Understanding the interaction between energy storage parameters (e.g., round-trip efficiency, degradation, service life, and production burden) and grid application parameters (e.g., generators' heat rates) can inform the relative importance of each parameter in determining the environmental performance of utilizing energy storage, which is the focus of this study. In 2012, Hittinger et al. evaluated the impact of energy storage parameters on the economic cost of providing energy service across grid applications [39]. The study presented here is novel, however, because it identifies how these parameters drive environmental outcomes in grid applications, providing new insights for energy storage designers, operators, and utilities. 
This analysis is informed by the twelve principles for green energy storage systems, which detail key drivers for improving environmental performance when integrating energy storage systems in grid applications [2]. The principles address the importance of the operational parameters of energy storage such as service life, round-trip efficiency, and degradation but do not address how to deal with trade-offs and competing objectives. Motivated and guided by this framework, we have developed universal equations to address the conflicts among the principles. In this model, the viable energy storage technologies for the given application are determined based on the required performance characteristics. The influence of parameters on the environmental outcomes is investigated using the universal equations, providing insights into the design and deployment of new technologies and the modification and improvement of existing ones. Three examples of energy storage applications- energy time-shifting, frequency regulation, and power reliability applications- are selected to demonstrate the impact of parameters on the results. These grid applications were chosen to illustrate a wide range of performance requirements such as required energy storage power rating, capacity, and number of cycles.

\section{C ase studies: Energy Time-shifting, F requency Regulation, and Power Reliability}

The first case study examined is the application of energy storage for bulk energy time-shifting. The minimum and maximum size range studied for energy storage in this application is $1 \mathrm{MW}$ to $3 \mathrm{GW}$, with discharge duration between 2 to 10 hours, operated at 300 to 400 cycles per year [25] [28] [40]. For the electric energy time-shifting application, several energy storage technologies offer the most suitable characteristics: pumped-hydro storage, flow batteries, lead-acid batteries, sodiumsulfur batteries, and compressed-air energy storage [25].

In the second application, energy storage provides frequency regulation services. Frequency regulation involves managing the momentary variations between demand and supply in order to maintain grid frequency [41]. Frequency regulation has been typically provided by generation resources, which are online and are able to change their power output quickly. However, generators that are used for this application may not operate at partial/variable load efficiently, incurring more air emissions and wear and tear when not operating at constant load [28]. Several energy storage systems can be suitable alternatives for this application, due to their ability to change output rapidly (i.e., fast ramp rate) and efficiently. These technologies include flywheels, capacitors, Li-ion 
batteries, and advanced lead-acid batteries [28]. The size range studied for this application is $1 \mathrm{M} \mathrm{W}$ to $100 \mathrm{M} \mathrm{W}$ with a short discharge duration of 15 minutes and 8,000 cycles per year [25], [28].

The third application considered in this study is energy storage used for commercial and industrial power reliability. In case of a complete power failure that lasts more than a few seconds, the storage technology provides enough energy to compensate for outages of extended duration, to complete an orderly shutdown of processes, and/or to transfer to on-site generation resources [28]. In this application, we explore minimum and maximum of 0.05 to $1 \mathrm{M} \mathrm{W}$ energy storage sizing with 4 to 10 hours of discharge duration. Also, it is assumed that energy storage used for this application experiences 50 cycles per year, which are far fewer compared to the other two applications [25]. A dvanced lead-acid, sodium-sulfur, Li-ion, and flow batteries have shown promising applicability for power reliability [25], [27].

Table 1 summarizes the potential energy storage technologies for each grid application.

Table 1. Selected Energy Storage System for Each Grid A pplication

\begin{tabular}{|c|c|c|c|}
\hline & Time-Shifting & Frequency Regulation & Power R eliability \\
\hline vanadium redox flow battery (VRFB) & $\checkmark$ & & $\checkmark$ \\
\hline lead-acid batteries (PbA) & $\checkmark$ & $\checkmark$ & $\checkmark$ \\
\hline sodium-sulfur batteries (NaS) & $\checkmark$ & & \\
\hline compressed-air energy storage (CAES) & $\checkmark$ & & \\
\hline pumped-hydro storage (PHES) & $\checkmark$ & & $\checkmark$ \\
\hline Li-ion batteries (Li-ion) & & $\checkmark$ & \\
\hline flywheels & & $\checkmark$ & \\
\hline capacitors & & $\checkmark$ & \\
\hline
\end{tabular}

\section{Methods}

A set of universal equations is developed to investigate the influence of various parameters on the environmental impact of using energy storage systems, which will be applied to time-shifting, frequency regulation, and power reliability applications. A lthough these equations can be applied to 
other grid applications, these three were selected to highlight a diverse set of applications that offer distinct differences in their charging patterns and technical requirements. Later, analysis is conducted to illustrate the interaction of parameters within the universal equations and highlight the importance of each parameter on environmental benefits.

\subsection{Universal Model Equations}

M otivated by the twelve principles for green energy storage systems in grid applications [2], we developed a set of universal equations to evaluate the net emissions (NET) including upstream and use-phase emissions during the operation of an energy storage system. For example, one of the principles (Principle\#1: Charge clean and displace dirty.) emphasizes charging energy storage with low emissions sources and using the stored electricity to displace higher emitting generation. The aim is to decrease the emissions during the use-phase of an energy storage system [2]. In other words, this principle considers the marginal units that are dispatched to charge the energy storage system as well as the marginal units that are displaced by energy storage within an interconnected grid [2]. A nother principle (Principle\#11: Minimize the environmental impact per unit of energy service for material production and processing.) highlights the necessity to minimize the production burden (upstream emissions) of energy storage systems.

The net emissions (NET) during the development and deployment of an energy storage system are comprised of use-phase emissions ( $\left.E_{\text {usephase }}\right)$ and energy storage upstream emissions ( $E_{\text {upstream}}$ ) ( $E q$. 1c). All emissions are defined in terms of $\mathrm{kg}$ of $\mathrm{CO}_{2 \text { eq }} / \mathrm{MWh}$. In this study, we investigate $\mathrm{CO}_{2 \text { eq }}$ impact factor; however, this model can be applied to other impact factors as well. Eq. 1a shows that $E_{\text {usephase }}$ is a function of the following parameters:

round-trip efficiency of energy storage system ()

service life of energy storage system in years $(n)$

degradation as a yearly decrease in energy storage round-trip efficiency and capacity ( $\mathrm{deg}$ )

energy required to achieve a full state of charge given the storage system operating constraints in M Wh $\left(S_{c h}\right)$ 
grid energy displaced by a fully discharged storage system given the storage system operating constraints in M Wh ( $\left.S_{d i s}\right)$

fuel upstream emissions ( $\left.E_{u c h}, E_{u d i s}\right)$, and combustion emissions ( $\left.E_{C c h}, E_{C d i s}\right)$ associated with the electricity that charges the energy storage system and the displaced generation resource in $\mathrm{kg}$ of $\mathrm{CO}_{\text {2eq }} / \mathrm{M} \mathrm{M} \mathrm{B} \mathrm{tu}$

the heat rates of charging and displaced generation in $\mathrm{M} \mathrm{M} \mathrm{B} \mathrm{tu/M} \mathrm{Wh}\left(H R_{c h}, H R_{d i s}\right)$

number of annual full cycles that energy storage experiences during its operation within the application (cycle)

study lifetime in years $(T)$

Eq. $1 b$ shows that $E_{\text {upstream }}$ is a function of the following parameters:

production burden of the energy storage system, storage dependent burden in $\mathrm{kg}$ of $\mathrm{CO}_{2 \text { eql }}$ $\mathrm{MWh}\left(\right.$ ESBurden $\left._{s}\right)$

production burden of the energy storage system, power rating dependent in $\mathrm{kg}$ of $\mathrm{CO}_{\text {2eq }}$ / M W $\left(\right.$ ESBurden $\left._{p}\right)$

sizing of energy storage in terms of power rating $(P)$ and storage capacity $(S)$ in $\mathrm{M} \mathrm{W}$ and $\mathrm{MWh}$

service life of energy storage system in years $(n)$

study lifetime in years $(T)$ 


$$
\begin{aligned}
E_{\text {usephase }}= & \left\lfloor\frac{T}{n}\right\rfloor \\
& * \sum_{i=1}^{i=n}\left\{\frac{H R_{c h} *\left(E_{C c h}+E_{u c h}\right) *\left(S_{c h(i-1)}-\operatorname{deg} * S_{c h(i-1)}\right)}{\eta_{i-1}-\operatorname{deg} * \eta_{i-1}}\right. \\
& \left.-H R_{\text {dis }} *\left(E_{\text {Cdis }}+E_{\text {udis }}\right) *\left(S_{\text {dis }(i-1)}-\operatorname{deg} * S_{\text {dis }(i-1)}\right)\right\} * \text { cycle } \\
& +\sum_{i=1}^{i=T-\left[\frac{T}{n}\right] * n}\left\{\frac{H R_{c h} *\left(E_{C c h}+E_{u c h}\right) *\left(S_{\text {ch }(i-1)}-\operatorname{deg} * S_{\text {ch }(i-1)}\right)}{\eta_{i-1}-\operatorname{deg} * \eta_{i-1}}\right. \\
& \left.-H R_{\text {dis }} *\left(E_{C d i s}+E_{u d i s}\right) *\left(S_{\text {dis }(i-1)}-\operatorname{deg} * S_{\text {dis }(i-1)}\right)\right\} \\
& * \text { cycle } \quad(\text { Eq. } 1 a)
\end{aligned}
$$

As shown in Equations la through $1 \mathrm{c}, \mathrm{NET}$ in $\mathrm{kg}$ of $\mathrm{CO}_{2 \text { eq }}$ depends on two sets of parameters. The first group is related to the characteristics of energy storage technology, which are also addressed in principles for green energy storage systems (Principles\# 3, 4, 5, 6, 7, and 11) [2]. The second group of parameters is determined based on the grid application performance criteria. To illustrate the range of outcomes for net emissions during the operation of energy storage, a range of energy storage parameters and grid application parameters are assumed and provided in Tables 2 and 3. A full literature review was conducted to find a feasible range for parameters of potential energy storage systems that were suitable for each application.

In this model, the system boundary includes the use-phase emissions during operation of energy storage system, its production burden, and also the fuel upstream emissions of charging and displaced generation. It excludes emissions associated with the power plants construction. The 
replacement strategy of energy storage systems is also based on its service life $(n)$ and study lifetime $(T)$. For example, if an energy storage system is designed to have a service life of 6 years and the desired study lifetime is 20 years, then in this case three new storage systems are used for eighteen years, and the fourth system will be used for the remaining two years. The full production burden of the fourth system is allocated based on the ratio between the remaining project lifetime and the total service life of the energy storage system. Study lifetime $(T)$ is assumed to be 20 years for all three applications and the index $(i)$ is used to trace the drop in round-trip efficiency and storage capacity per year due to degradation. Two scenarios are assumed: 1) energy storage is charged with natural gas (NG) fuel and is used to displace coal based electricity generation to test the impact of parameters on net emissions through the lens of increasing the environmental performance, 2) energy storage is charged with coal based electricity generation and displaces NG to test the impact of parameters in a scenario that is closer to some real world applications. We assume that a safe operating window for the energy storage is 10-90 percent state of charge (i.e. $\left.S_{c h}=0.9 * S, S_{d i s}=0.8 * \mathrm{~S}\right)$.

Table 2. Possible Ranges for Energy Storage Systems Parameters*

\begin{tabular}{|c|c|c|c|c|c|c|c|c|}
\hline \multicolumn{2}{|c|}{ Parameter } & Variable & VRFB & PbA & NaS & CAES & PHES & Li-ion \\
\hline \multicolumn{2}{|c|}{$\begin{array}{c}\text { Round-trip efficiency (\%) [3] } \\
\text { [33], [34] [40] [42] [43] [44] [45] } \\
\text { [46] [47] [48] [49] }\end{array}$} & & $70-95$ & $70-90$ & $71-90$ & $45-89$ & $75-85$ & $70-90$ \\
\hline \multicolumn{2}{|c|}{$\begin{array}{c}\text { Service life (years) [42][43], } \\
\text { [47], [50] }\end{array}$} & & $5-15$ & $3-15$ & $5-15$ & $20-60$ & $40-60$ & $5-20$ \\
\hline \multicolumn{2}{|c|}{$\begin{array}{l}\text { A nnual Degradation (\%/year) } \\
\text { [51] [52] [53] [54] [55] [56] }\end{array}$} & & $0-3$ & $0-3$ & $0-3$ & $0-3$ & $0-3$ & $0-3$ \\
\hline \multirow{2}{*}{$\begin{array}{c}\text { Energy } \\
\text { Storage } \\
\text { Production } \\
\text { Burdens [3] } \\
\text { [6] [7] [9] } \\
{[11][17]} \\
{[57][58]} \\
{[59][60]} \\
{[61][62]}\end{array}$} & $\begin{array}{c}\text { Storage } \\
\text { dependent }(\mathrm{kg} \text { of } \\
\left.\mathrm{CO}_{\text {2eq }} / \mathrm{M} \mathrm{Wh}\right)\end{array}$ & & $\begin{array}{c}47,400-1 \\
61,400\end{array}$ & $\begin{array}{c}18,000-211 \\
, 866\end{array}$ & $\begin{array}{c}7,200-12 \\
8,440\end{array}$ & 19,400 & 35,700 & $\begin{array}{c}61,000-4 \\
87,000\end{array}$ \\
\hline & $\begin{array}{l}\text { Power Rating } \\
\text { dependent* } \\
\text { (kg of } \mathrm{CO}_{2 \text { eq }} / \\
\text { M W ) }\end{array}$ & & 160,000 & 160,000 & 160,000 & 160,000 & 160,000 & 160,000 \\
\hline
\end{tabular}

* Flywheel and capacitors are not included in the analysis due to the lack of availability of data for their production burden. A range could not be found for CAES and PHES production burdens in the literature. 
** This component of energy storage production burden is held constant due to the lack of availability of data.

Table 3. G rid A pplication A ssumptions

\begin{tabular}{|c|c|c|c|}
\hline \multicolumn{2}{|c|}{ Parameter } & Variable & Value \\
\hline \multirow{2}{*}{$\begin{array}{c}\text { Natural Gas } \\
\text { Emissions Factor }\end{array}$} & $\begin{array}{c}\text { Upstream ( } \mathrm{kg} \text { of } \mathrm{CO}_{2 \mathrm{eq}} / \\
\text { M M B tu) [63] }\end{array}$ & & 13.63 \\
\hline & $\begin{array}{l}\text { Combustion (kg of } \\
\mathrm{CO}_{\text {2eq }} / \mathrm{M} \text { M B tu) [64] }\end{array}$ & & 53 \\
\hline \multirow{2}{*}{$\begin{array}{c}\text { Coal Emissions } \\
\text { Factor }\end{array}$} & $\begin{array}{c}\text { Upstream ( } \mathrm{kg} \text { of } \mathrm{CO}_{2 \text { 2eq }} \\
\text { M M B tu) [63] }\end{array}$ & & 5.6 \\
\hline & $\begin{array}{l}\text { Combustion (kg of } \\
\mathrm{CO}_{\text {2eq }} / \mathrm{M} \text { M B tu) [64] }\end{array}$ & & 97 \\
\hline \multirow{2}{*}{$\begin{array}{c}\text { H eat Rates } \\
\text { (M M B tu/M W h) } \\
{[65]}\end{array}$} & N atural Gas Generator & & $7-13$ \\
\hline & Coal Generator & & $9-12$ \\
\hline \multirow{3}{*}{ Power Rating (M W) } & Time-Shifting & & $1-3,000$ \\
\hline & Frequency R egulation & & $1-100$ \\
\hline & Power Reliability & & $0.05-1$ \\
\hline \multirow{3}{*}{ Size (M Wh) } & Time-Shifting & & $2-30,000$ \\
\hline & Frequency R egulation & & $0.25-25$ \\
\hline & Power Reliability & & $0.2-10$ \\
\hline \multirow{3}{*}{$\begin{array}{l}\text { N umber of Full } \\
\text { Cycles () [25] }\end{array}$} & Time-Shifting & & 350 \\
\hline & Frequency R egulation & & 8,000 \\
\hline & Power Reliability & & 50 \\
\hline \multicolumn{2}{|c|}{ Study lifetime (year) } & & 20 \\
\hline
\end{tabular}

A set of two analyses, namely extreme parameter testing and Latin Hypercube Sampling, are conducted to investigate the impact of parameters on net emissions during operation of energy storage in each of the three applications, using model Equations la through 1c.

\subsection{Extreme Parameter Testing}


In this approach, net emissions are calculated using Equations la through 1c by holding all parameters constant at their average values (shown in Table 4) except for one parameter that is varied between minimum and maximum ranges. These calculations are repeated for the six parameters of each storage technology that is suitable for each of time-shifting, frequency regulation, and power reliability grid applications (Table 1). These parameters are round-trip efficiency, service life, annual degradation, production burdens, and heat rates of charging and displaced generations. The objective is to compare the dominance of each parameter over net, usephase, and upstream emissions. To illustrate the results, the net emissions results for lead-acid (PbA) battery technology are shown in Fig. 1 as spider diagrams.

Table 4. D efault Values for Spider Diagrams

\begin{tabular}{|c|c|c|c|c|c|c|c|c|}
\hline \multicolumn{2}{|c|}{ E nergy Storage Parameter } & Variable & VRFB & $\mathrm{PbA}$ & NaS & CAES & PHES & Li-ion \\
\hline \multicolumn{2}{|c|}{ Round-trip efficiency (\%) } & & 82.5 & 80 & 80.5 & 67 & 80 & 80 \\
\hline \multicolumn{2}{|c|}{ Service life (years) } & $n$ & 10 & 9 & 10 & 40 & 50 & 13 \\
\hline \multicolumn{2}{|c|}{ A nnual Degradation (\%/year) } & deg & 1.5 & 1.5 & 1.5 & 1.5 & 1.5 & 1.5 \\
\hline \multirow{2}{*}{$\begin{array}{c}\text { Energy Storage } \\
\text { Production } \\
\text { Burdens }\end{array}$} & $\begin{array}{l}\text { Storage } \\
\text { dependent } \\
\left(\mathrm{kg} \text { of } \mathrm{CO}_{\text {2eq }} /\right. \\
\mathrm{M} \mathrm{Wh})\end{array}$ & ESB urden $_{s}$ & 104,400 & 114,933 & 67,820 & 19,400 & 35,700 & 274,000 \\
\hline & $\begin{array}{l}\text { Power Rating } \\
\text { dependent } \\
\text { (kg of } \mathrm{CO}_{2 \text { eq }} / \\
\mathrm{MW} \text { ) }\end{array}$ & ESB urdenp & 160,000 & 160,000 & 160,000 & 160,000 & 160,000 & 160,000 \\
\hline \multicolumn{2}{|c|}{ Grid A pplication Parameter } & Variable & \multicolumn{2}{|c|}{ Time-shifting } & \multicolumn{2}{|c|}{$\begin{array}{l}\text { Frequency } \\
\text { Regulation }\end{array}$} & \multicolumn{2}{|c|}{ Power R eliability } \\
\hline \multirow{2}{*}{$\begin{array}{c}\text { Heat Rates } \\
\text { (M M B tu/M W h) }\end{array}$} & $\begin{array}{l}\text { N atural Gas } \\
\text { Generator }\end{array}$ & $H R_{c h}$ & \multicolumn{2}{|c|}{10} & \multicolumn{2}{|c|}{10} & \multicolumn{2}{|c|}{10} \\
\hline & $\begin{array}{c}\text { Coal } \\
\text { Generator }\end{array}$ & $H R_{\text {dis }}$ & \multicolumn{2}{|c|}{10.5} & \multicolumn{2}{|c|}{10.5} & \multicolumn{2}{|c|}{10.5} \\
\hline \multicolumn{2}{|c|}{ Power Rating (M W) } & $P$ & \multicolumn{2}{|c|}{1,500} & \multicolumn{2}{|c|}{50} & \multicolumn{2}{|c|}{0.5} \\
\hline \multicolumn{2}{|c|}{ Size (M Wh) } & $\mathrm{S}$ & \multicolumn{2}{|c|}{15,000} & \multicolumn{2}{|c|}{12.5} & \multicolumn{2}{|c|}{5} \\
\hline \multicolumn{2}{|c|}{ Number of Cycles } & Cycle & \multicolumn{2}{|c|}{350} & \multicolumn{2}{|c|}{8,000} & \multicolumn{2}{|c|}{50} \\
\hline
\end{tabular}




\subsection{L atin Hypercube Sampling}

Latin Hypercube Sampling (LHS) is a statistical modeling technique to generate controlled random samples [66]. In this study, LHS is used to generate sample values for energy storage parameters and grid application parameters (round-trip efficiency, service life, annual degradation, production burdens, and heat rates) within their ranges provided in Table 2 and Table 3. Parameter sets were generated from 70,000 samples. Therefore, in each round, random values are created for each parameter within its lower and higher bound. The ranges are defined for each feasible storage system for each of time-shifting, frequency regulation, and power reliability applications. Based on the generated samples, the net emissions during the operation of energy storage are calculated using Equations 1a through 1c. This calculation is repeated 70,000 times with different sample parameter sets to provide an inclusive range of possibilities. The goal is to demonstrate the impact of each parameter on net emissions, for scenarios that span plausible outcomes for the other parameters.

Since a range of storage sizing is assumed for each grid application, two scenarios are createdminimum size scenario and maximum size scenario- and parameter sets are created in each scenario. The ranges studied for energy storage sizing are provided earlier for each application. The results of the minimum size scenario are presented in the Results section, and the results of the maximum size scenario are provided in A ppendix A .

\section{R esults}

Fig. 1 shows the comparison among the impact of each parameter on net emissions in case of lead acid $(\mathrm{PbA})$ battery technology. The results of other technologies are provided in A ppendix $\mathrm{B}$. For each parameter, minimum, maximum, and average values are provided in Tables 2 through 4 . In this figure, the influence of round-trip efficiency, energy storage service life, annual degradation, heat rates of charging and displacing technologies, and production burden of energy storage are demonstrated. For example, increasing round-trip efficiency leads to environmental improvement across all three applications. On the other hand, among the three applications, power reliability is the only one in which production burden dominates over the net emissions. Increasing energy storage service life reduces the net emissions in the reliability application significantly. 


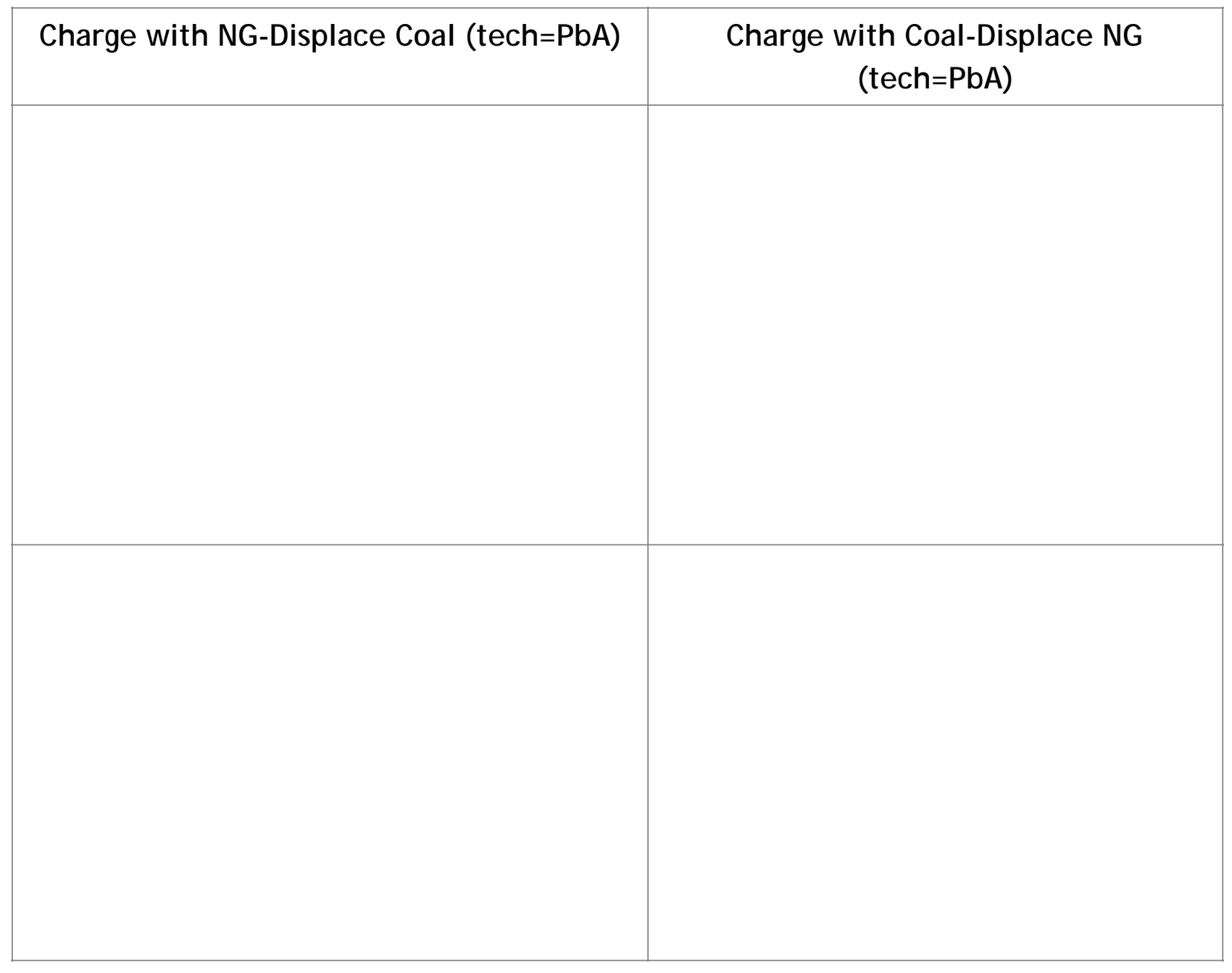




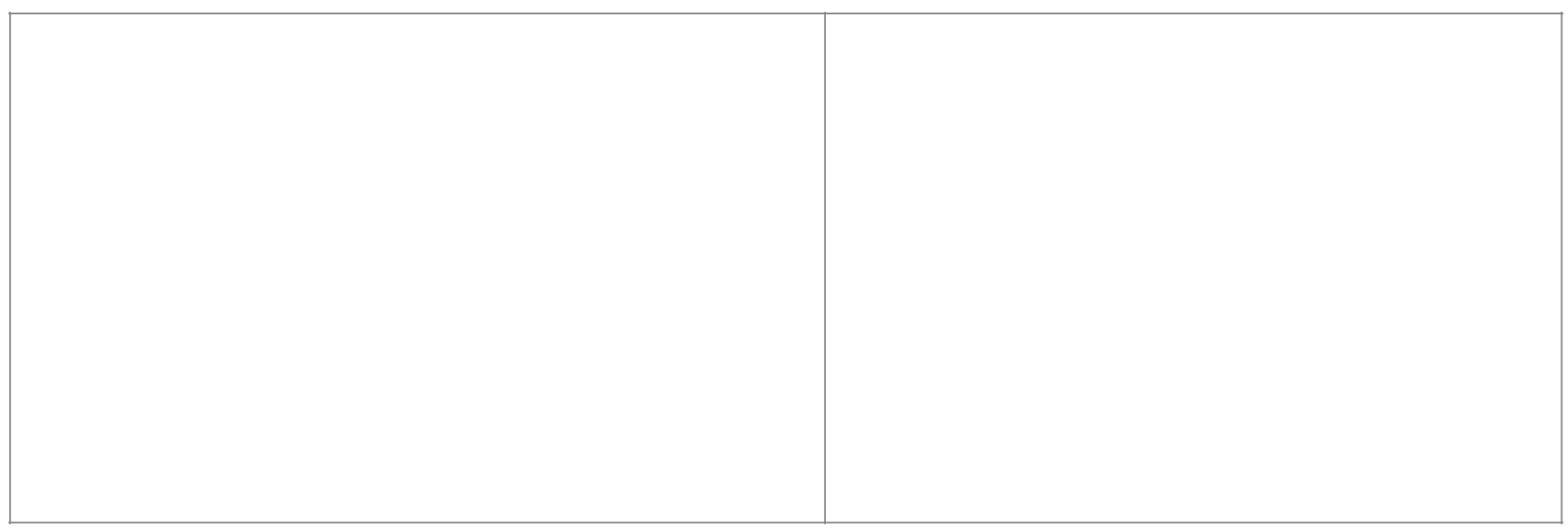

$\begin{array}{lll}\text { Round-trip efficiency } & \text { - Service-life } & \text { Degradation } \\ \text { Heat Rate Charge } & \text { - Heat Rate Displace } & \text { - ES Burden }(\mathrm{kg} / \mathrm{MWh})\end{array}$

Figure 1. I mpacts of each parameter on $\mathrm{CO}_{2 \text { eq }}$ net emissions in three applications: time-shifting application, frequency regulation, and power reliability in case of PbA technology. Two scenarios are assumed: 1) energy storage is charged with natural gas, and displaces coal based electricity generation, 2) energy storage is charged with coal, and displaces natural gas generation. "ES Burden" stands for energy storage production burden. X-axis represents the minimum, average, and maximum values for each parameter. A ssumptions for values are provided in Tables 2 through 4.

The results from the spider diagrams (Fig. 1) are elaborated in Fig. 2, which shows net, use-phase, and upstream emissions in three values of minimum, average, and maximum for each parameter. As shown in this figure, use-phase and net emissions have similar patterns in time-shifting and frequency regulation applications. They are influenced by round-trip efficiency and heat rates greatly due to the higher number of cycles in these applications.

In power reliability, increasing service life would have major environmental benefits. The reason is that energy storage is not utilized frequently in this application and it does not experience severe degradation. In this application, energy storage production burden ( $\mathrm{kg}$ of $\mathrm{CO}_{\text {2eq }} / \mathrm{M} \mathrm{Wh}$ ) has a large impact on upstream and net emissions. Overall, upstream emissions have a larger contribution in net emissions in the power reliability application. 

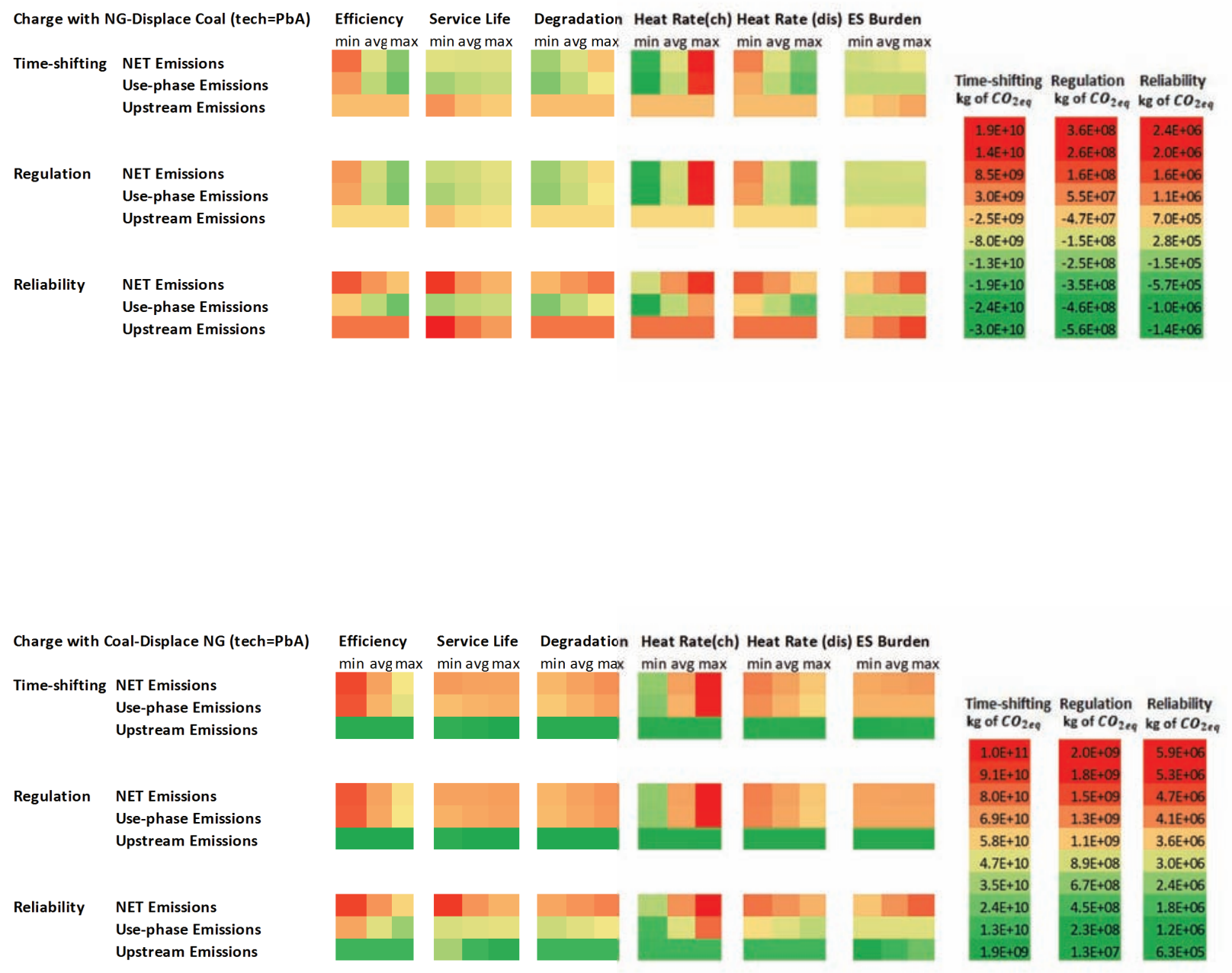

Figure 2. D ominance of parameters over upstream, use-phase, and net emissions in time-shifting, frequency regulation, and reliability applications in case of $\mathrm{PbA}$ technology. Two scenarios are assumed: 1 ) energy storage is charged with natural gas, and displaces coal based electricity generation, 2) energy storage is charged with coal, and displaces natural gas generation. "ES B urden" stands for energy storage production burden. The color scales vary by application and charging pattern.

Figures 3 to 5 show the results of LHS modeling for each parameter in the minimum energy storage size scenario in three applications: energy time-shifting, frequency regulation, and power reliability. The results of maximum size scenario are provided in Appendix A. As shown in these figures, round-trip efficiency has a significant impact on net emissions in time-shifting and frequency regulation applications, in which energy storage is used more frequently (higher number of cycles). Higher utilization of energy storage results in the dominance of use-phase emissions, which are greatly influenced by round-trip efficiency (as shown in Eq.1a). This is also applicable to generator heat rates, and related diagrams show a higher slope in energy time-shifting and frequency regulation applications. 
Increasing energy storage service life would reduce the emissions due to a lower energy storage utilization rate in the power reliability application (Fig. 5). One of the twelve principles for green energy storage is to operate such systems with optimal service life (Principle\# 6) [2]. This comparison across applications gives insights to energy storage operators on substituting strategies.

As shown in Fig.5, the energy storage production burden ( $\mathrm{kg}$ of $\mathrm{CO}_{2 e q} / \mathrm{MWh}$ ) has a significant impact in the power reliability application due to a low number of cycles (i.e., low utilization of energy storage during its lifetime). Therefore, in this application upstream emissions associated with the production of the energy storage system dominate. For a higher production burden of $2.5^{*} 10^{5} \mathrm{~kg}$ of $\mathrm{CO}_{2 \text { eq }} / \mathrm{MWh}$, integrating energy storage in this application would yield positive net emissions. Therefore, minimizing the environmental impact per unit of energy service for material production and processing, as listed in Principle\#11, has a more significant influence on environmental performance in specific grid applications. 


\section{Time Shifting}
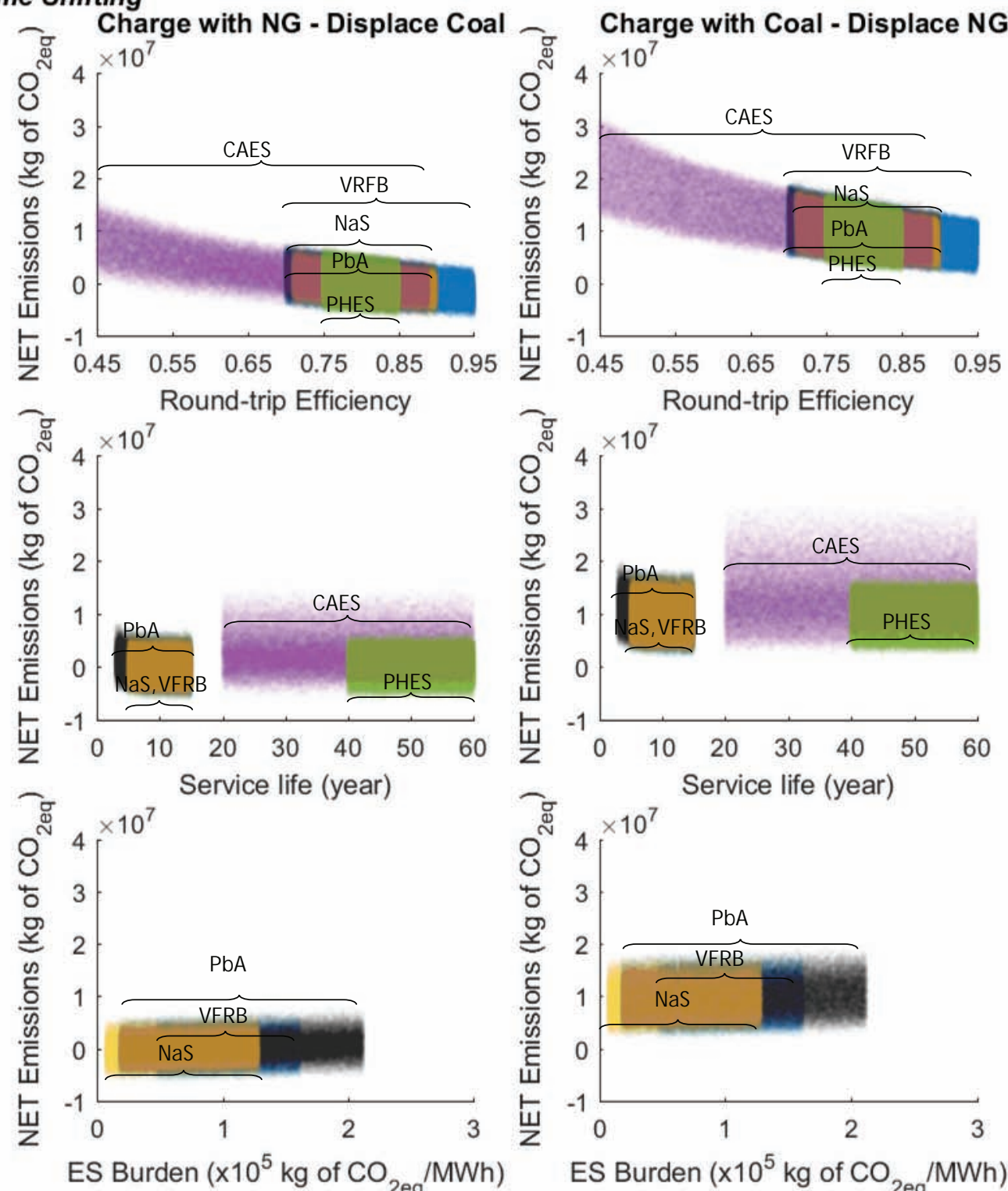

$$
\text { ES Burden }\left(x 10^{5} \mathrm{~kg} \text { of } \mathrm{CO}_{2 \mathrm{eq}} / \mathrm{MWh}\right) \quad \text { ES Burden }\left(\times 10^{5} \mathrm{~kg} \text { of } \mathrm{CO}_{2 \mathrm{eq}} / \mathrm{MWh}\right)
$$

$0^{\text {VRFB }} 0^{\text {PbA }} 0^{\text {NaS }} \overbrace{}^{\text {CAES }} \overbrace{}^{\text {PHES }}$


Time Shifting

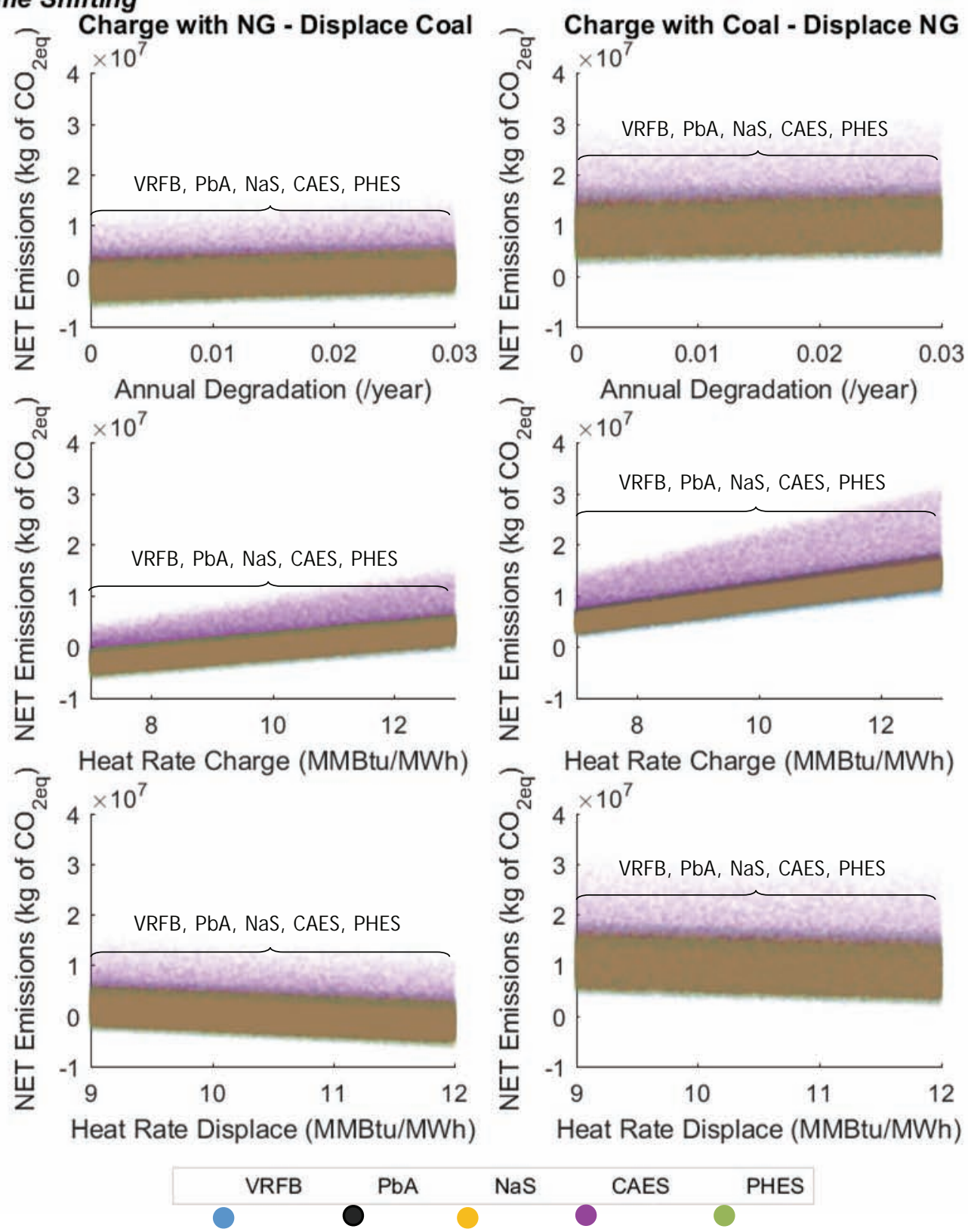

Figure 3. Impacts on life cycle $\mathrm{CO}_{2 \text { eq }}$ emissions due to assumptions for energy storage round-trip efficiency, energy storage service life, energy storage production burden, annual degradation in energy storage capacity and round-trip efficiency, heat rate of charging technology, and heat rate of displaced technology in time-shifting application (minimum size scenario). Two scenarios are assumed: 1) energy storage is charged with natural gas, and displaces coal based electricity generation (left column), 2) energy storage is charged with coal, and displaces natural gas generation (right column) 

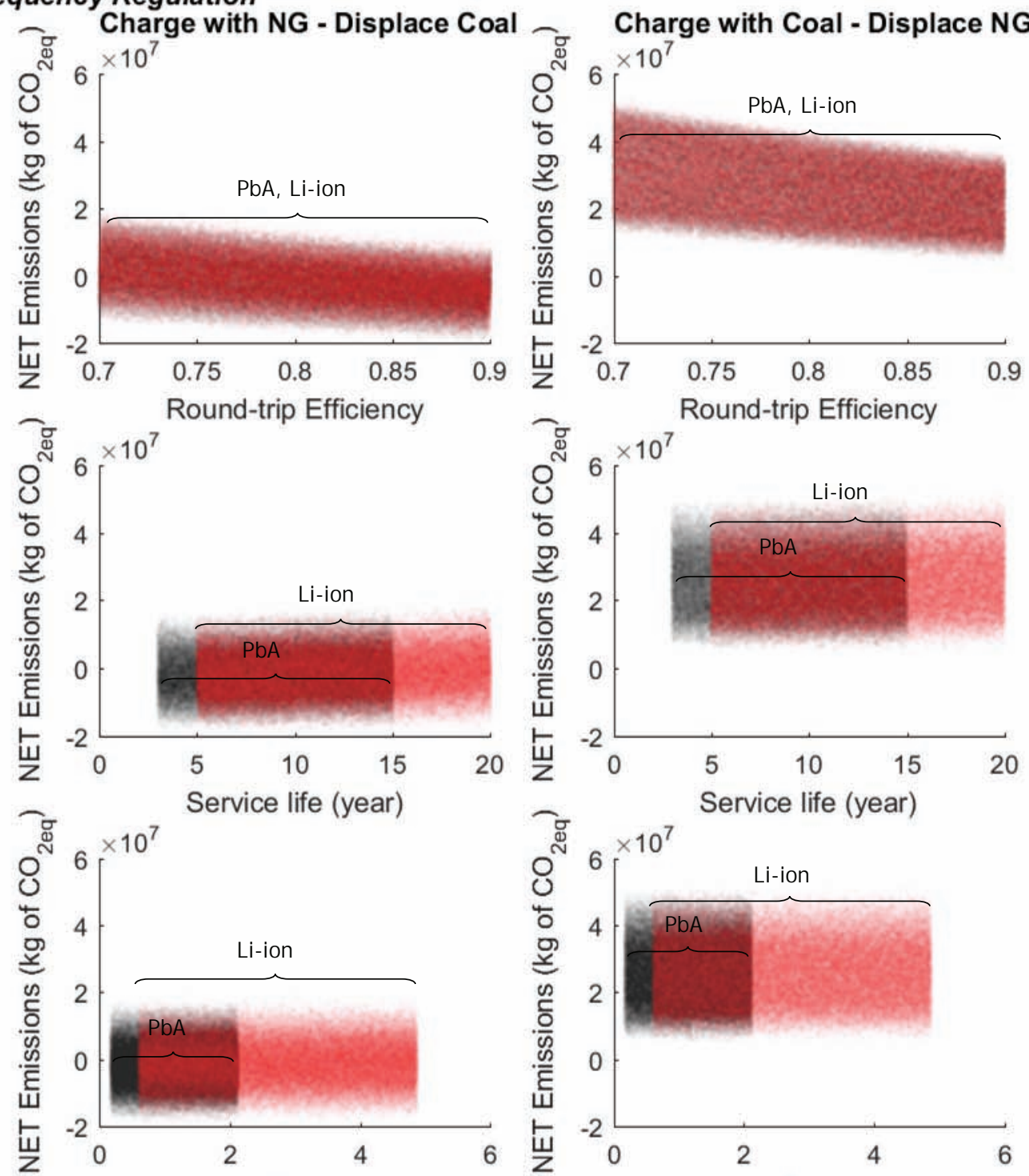

ES Burden $\left(x 10^{5} \mathrm{~kg}\right.$ of $\left.\mathrm{CO}_{2 \mathrm{eq}} / \mathrm{MWh}\right) \quad \mathrm{ES}$ Burden $\left(x 10^{5} \mathrm{~kg}\right.$ of $\left.\mathrm{CO}_{2 \mathrm{eq}} / \mathrm{MWh}\right)$

$0^{\mathrm{PbA}} \mathrm{0}^{\mathrm{Li}-\mathrm{i} i \mathrm{n}}$




\section{Frequency Regulation}
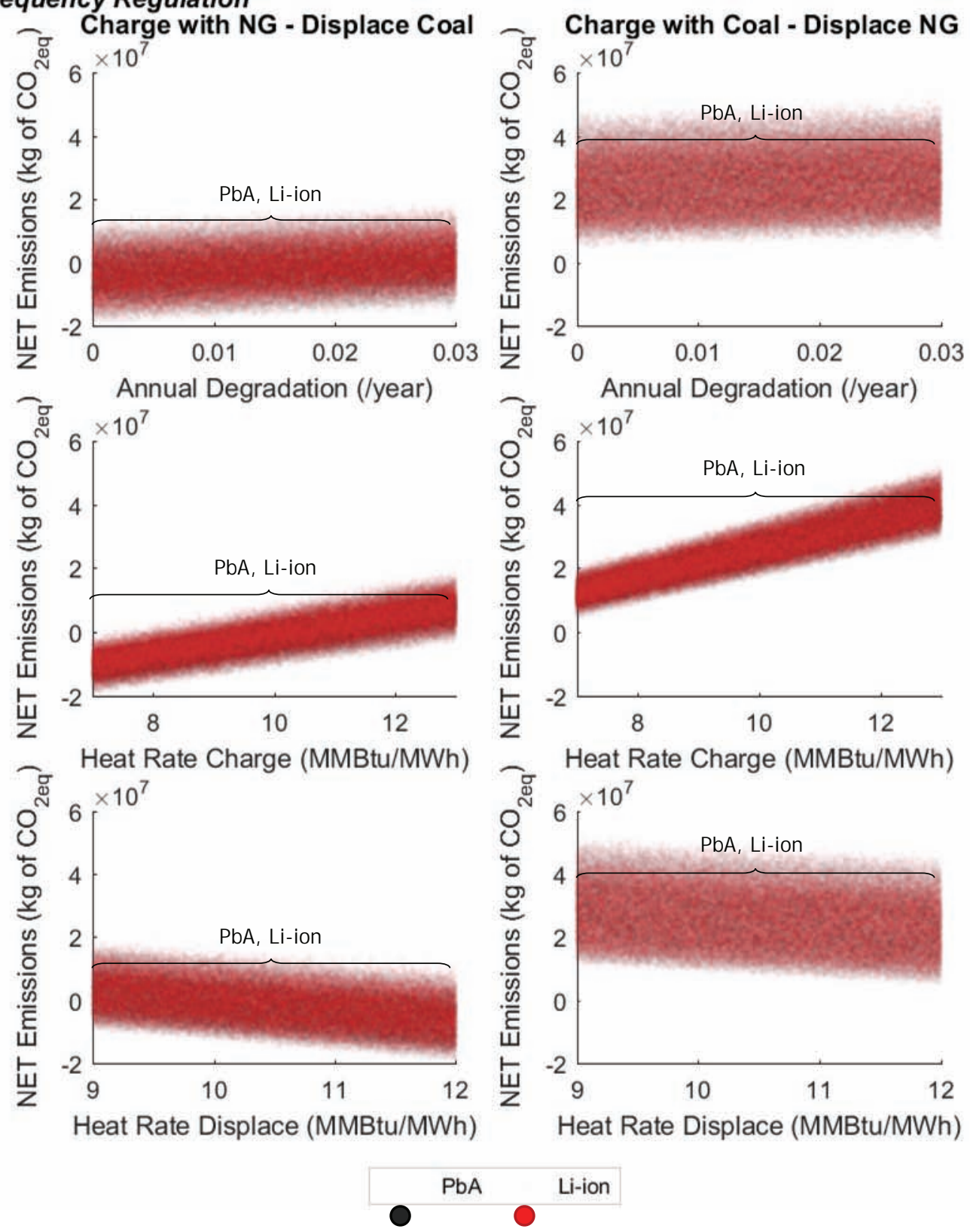

Figure 4. Impacts on life cycle $\mathrm{CO}_{2 \text { eq }}$ emissions due to assumptions for energy storage round-trip efficiency, energy storage service life, energy storage production burden, annual degradation in energy storage capacity and round-trip efficiency, heat rate of charging technology, and heat rate of displaced technology in F requency Regulation application (minimum size scenario). Two scenarios are assumed: 1 ) energy storage is charged with natural gas, and displaces coal based electricity generation (left column), 2) energy storage is charged with coal, and displaces natural gas generation (right column) 


\section{Power Reliability}
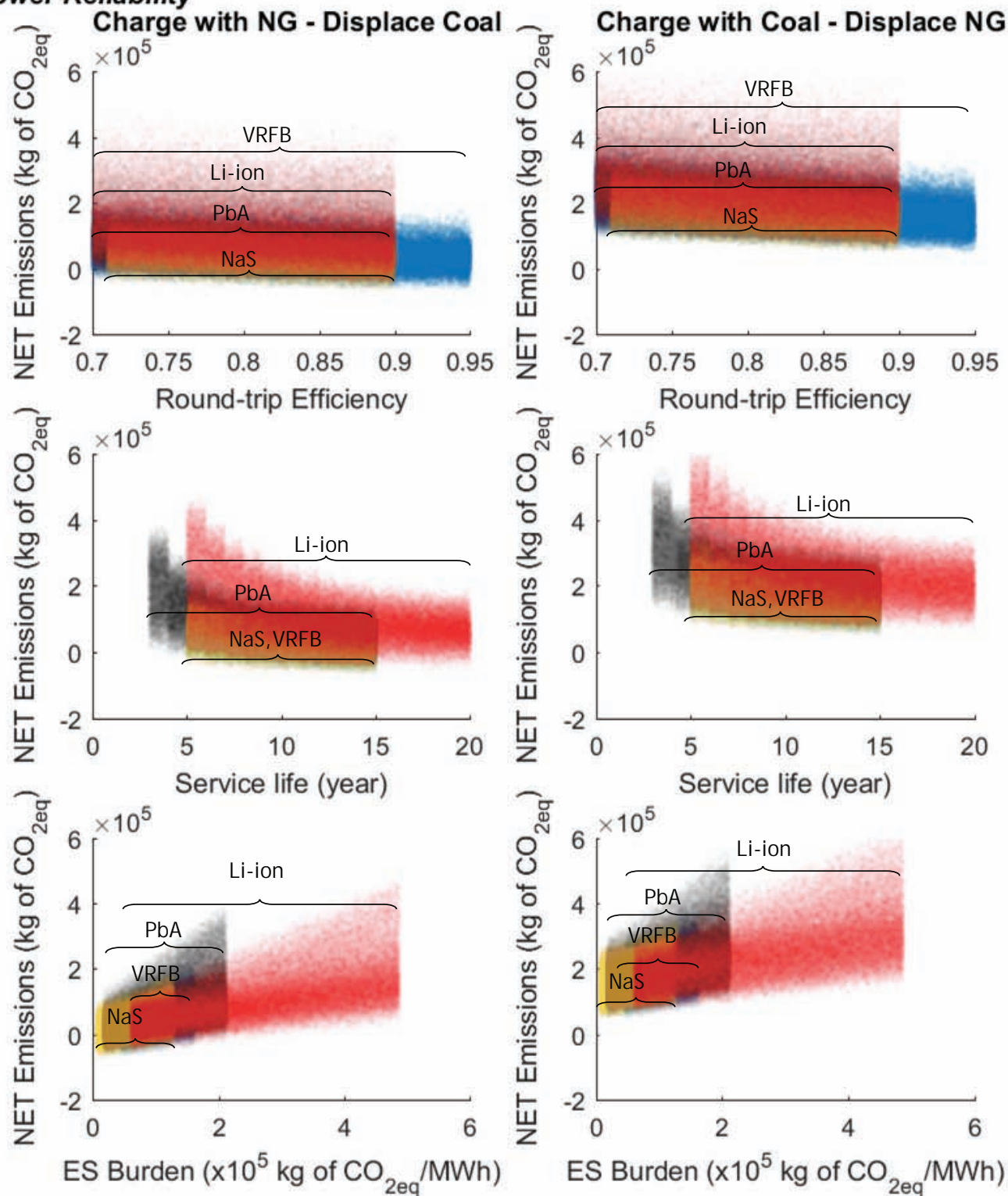

ES Burden $\left(x 10^{5} \mathrm{~kg}\right.$ of $\left.\mathrm{CO}_{2 \mathrm{eq}} / \mathrm{MWh}\right) \quad \mathrm{ES}$ Burden $\left(x 10^{5} \mathrm{~kg}\right.$ of $\left.\mathrm{CO}_{2 \mathrm{eq}} / \mathrm{MWh}\right)$

$0^{\text {VRFB }} \bullet^{\mathrm{PbA}} \overbrace{}^{\mathrm{NaS}} \bullet^{\text {Li-ion }}$




\section{Power Reliability}

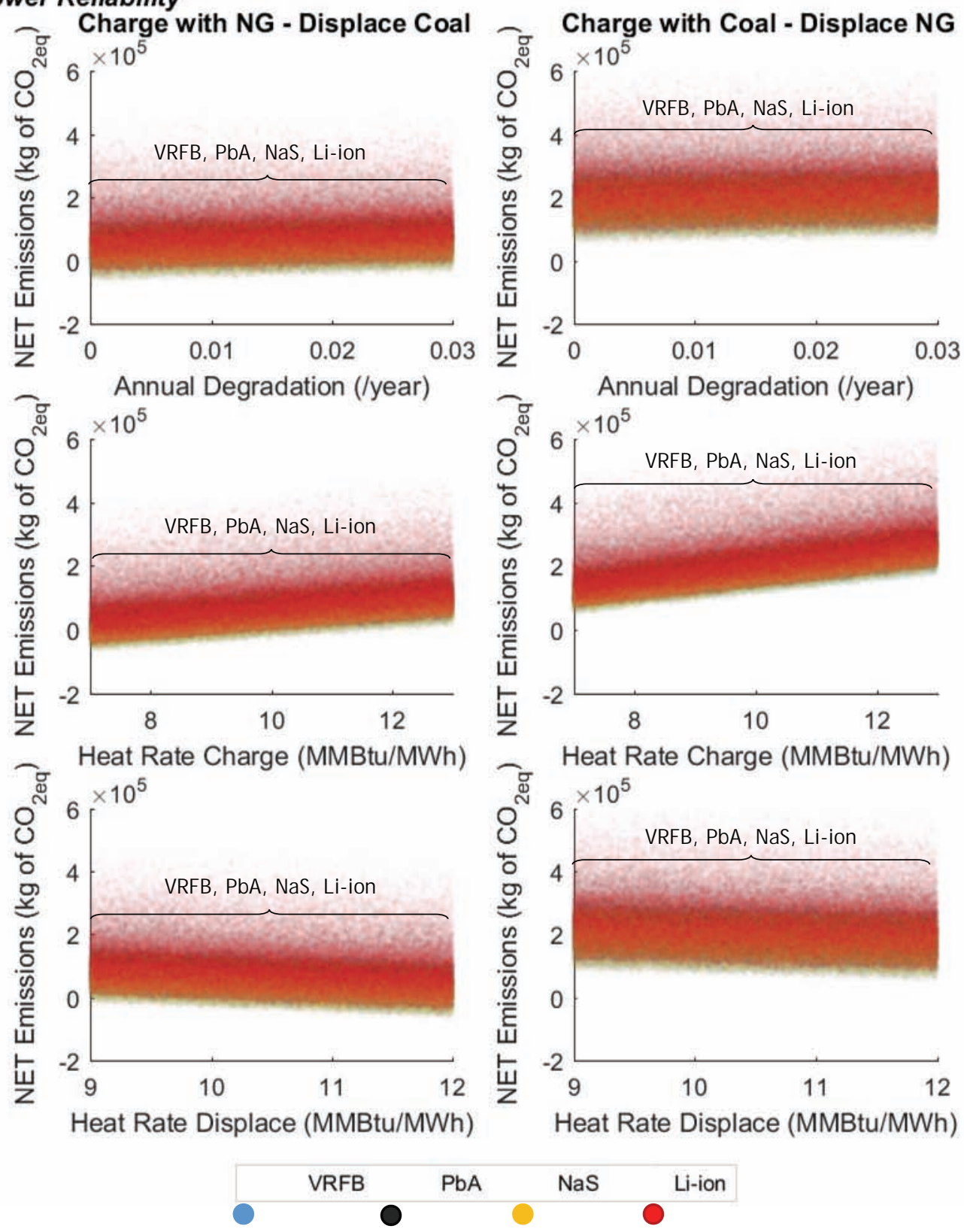

Figure 5. Impacts on life cycle $\mathrm{CO}_{2 \text { eq }}$ emissions due to assumptions for energy storage round-trip efficiency, energy storage service life, energy storage production burden, annual degradation in energy storage capacity and round-trip efficiency, heat rate of charging technology, and heat rate of displaced technology in power reliability application (minimum size scenario). Two scenarios are assumed: 1) energy storage is charged with natural gas, and displaces coal based electricity generation (left column), 2) energy storage is charged with coal, and displaces natural gas generation (right column)

\section{Discussion}

In this study, model equations are developed to analyze the impact of selected parameters on environmental performance of energy storage systems during their production and deployment in 
the electric grid. The selected parameters represent key factors addressed in twelve principles for green energy storage in grid applications [2], including round-trip efficiency, energy storage service life, annual degradation in energy storage capacity and round-trip efficiency, heat rates of charging and displacing technologies, and production burden of energy storage. In this study, first the grid application and potential energy storage alternatives were determined. N ext, motivated by twelve principles for green energy storage, two sets of parameters were identified: energy storage system parameters and grid application parameters. The interactions between these parameters were evaluated using a universal set of equations to analyze their dominance over environmental performance.

The impacts of selected parameters on net emissions are summarized in Table 5. This table simplifies and clarifies the relative differences of the parameters' influence across time-shifting, frequency regulation, and power reliability applications based on our baseline assumptions. As shown in this table, the energy storage round-trip efficiency, annual degradation, and generator heat rate have a moderate to strong influence over emissions in time-shifting and frequency regulation applications due to high utilization of energy storage.

On the other hand, energy storage production burden and service life have a strong influence on net emissions in the power reliability application. In this application, upstream emissions dominate due to fewer cycles of energy storage during its operation in this application. Lower utilization of energy storage also leads to far fewer net emissions in this application compared to the other two case studies.

Table 5. Influence of parameters on net $\mathrm{CO}_{2 \text { eq }}$ emissions in time-shifting, frequency regulation, and reliability applications

\begin{tabular}{|c|c|c|c|}
\hline & Time-shifting & Frequency Regulation & Power Reliability \\
\hline Round-trip efficiency & & & \\
\hline A nnual degradation & & & \\
\hline Heat rate charge & & & \\
\hline Heat rate displace & & & \\
\hline Service life & & & \\
\hline
\end{tabular}




\begin{tabular}{|c|l|l|l|}
\hline Energy storage & & \\
production burden & & & \\
\hline
\end{tabular}

Strong influence $\bigcirc \quad$ Moderate influence $\bigcirc$ Weak influence

To evaluate the results of enhanced environmental performance of energy storage integration and also to analyze some real world applications, we have assumed two scenarios: In the first scenario, energy storage is charged with natural gas, and the stored electricity displaces coal based electricity generation. In many real world applications, this is not the standard practice, given that natural gas is often more expensive that coal. To charge the energy storage with natural gas and displace coal based generation, there would likely need to be an inversion of coal and gas prices (e.g. driven by a carbon tax or $\mathrm{C} \mathrm{CO}_{2}$ cap) that could incentivize coal to gas switching. In the second scenario, energy storage is charged with a higher emitting generation such as coal and displaces natural gas. In this case, the relative influence of parameters is the same. However, this scenario leads to more net emissions during the operation of the energy storage system, fundamentally altering the approach for environmental pollution mitigation.

There are major uncertainties associated with the upstream emissions of natural gas [67]-[71], particularly the amount of methane leakage during natural gas production. If the life cycle emissions of the charging generation prove to be higher than displaced generation due to these emissions, the results would change the energy storage integration strategy.

In addition to environmental incentives, the economies of energy storage technologies is also a key driver in selecting the suitable technology for a specific application. The comparison among environmental and economic benefits of different storage technologies across grid applications is the focus of future research that will build upon our findings in this article.

As shown in this study, the integration of energy storage systems in different grid applications may not necessarily lead to environmental improvements. The environmental outcomes depend on the grid application and storage technology parameters. Understanding the interaction among such parameters, as analyzed here, can guide different stakeholders, who develop and manage energy storage systems. They include energy storage designers, operators, and utilities. This analysis can 
help them more systematically improve environmental performance by focusing on the most influential parameters in the development and deployment of energy storage systems.

\section{Acknowledgments}

This work was supported by the U.S. National Science Foundation's Sustainable Energy Pathways program (Grant \#1230236: Non-A queous Redox Flow B attery Chemistries for Sustainable Energy Storage), Dow Sustainability Fellows Program, and the University of Michigan Rackham Predoctoral Fellowship Program. The authors would also like to thank Shelie Miller and Shamitha K eerthi (University of Michigan) for their valuable contributions on this project and the Center for Sustainable System at the U niversity of M ichigan for intellectual support.

\section{Appendix A.}

The results of LHS modeling in maximum case scenario: 
Time Shifting
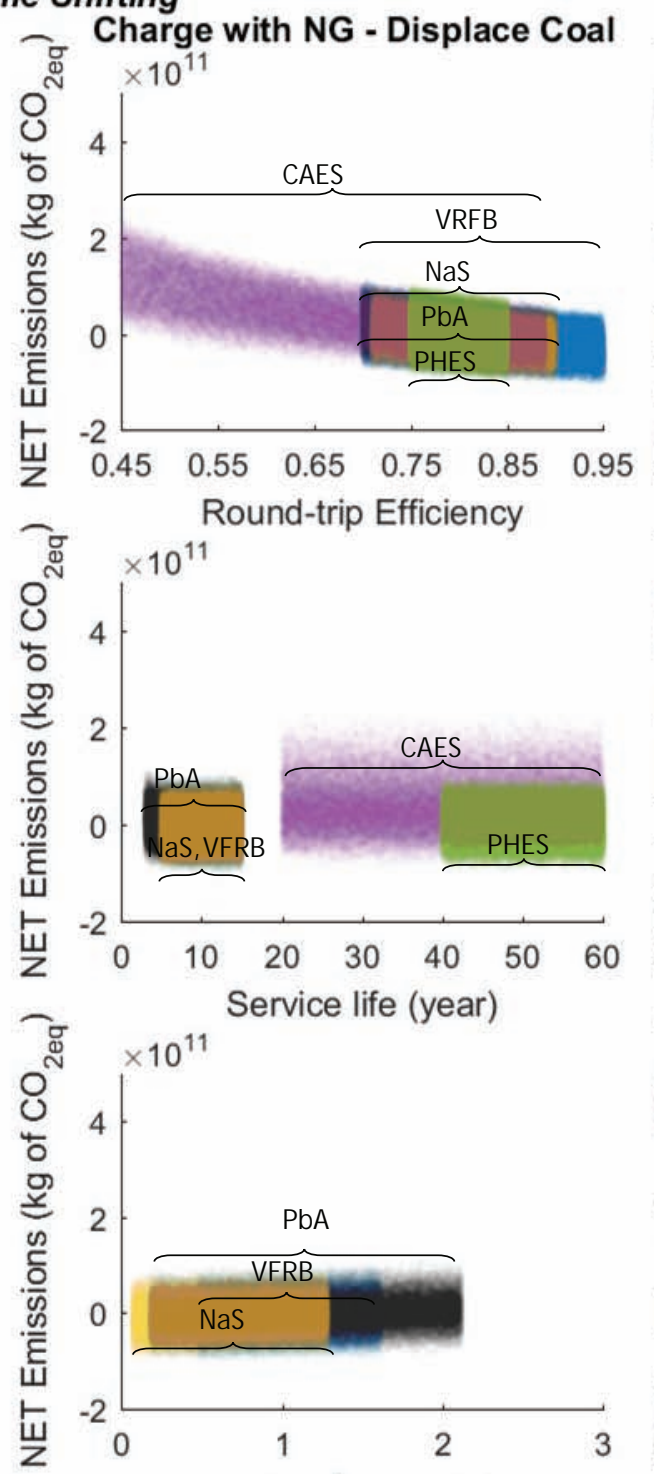

ES Burden $\left(\times 10^{5} \mathrm{~kg}\right.$ of $\left.\mathrm{CO}_{2 \mathrm{eq}} / \mathrm{MWh}\right)$
Charge with Coal - Displace NG

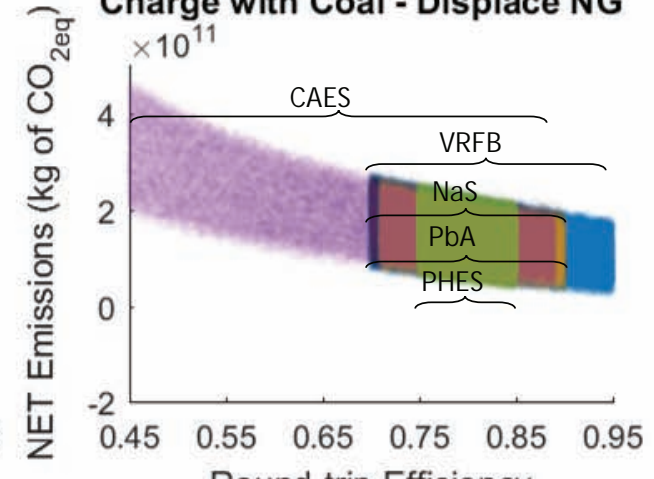

Round-trip Efficiency
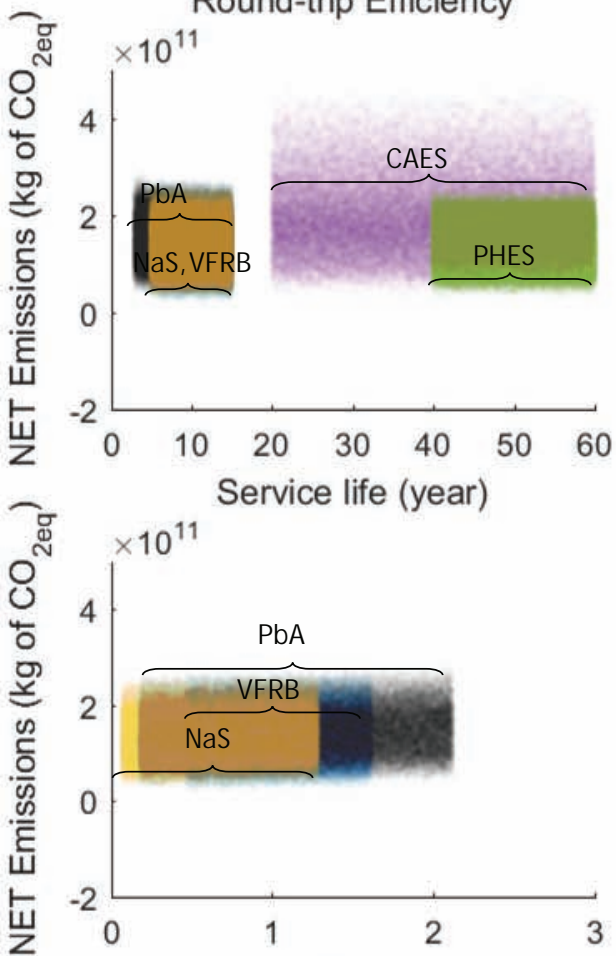

ES Burden $\left(\times 10^{5} \mathrm{~kg}\right.$ of $\left.\mathrm{CO}_{2 \mathrm{eq}} / \mathrm{MWh}\right)$

$0^{\text {VRFB }} 0^{\text {PbA }} 0^{\text {NaS }} 0^{\text {CAES }} 0^{\text {PHES }}$




\section{Time Shifting}
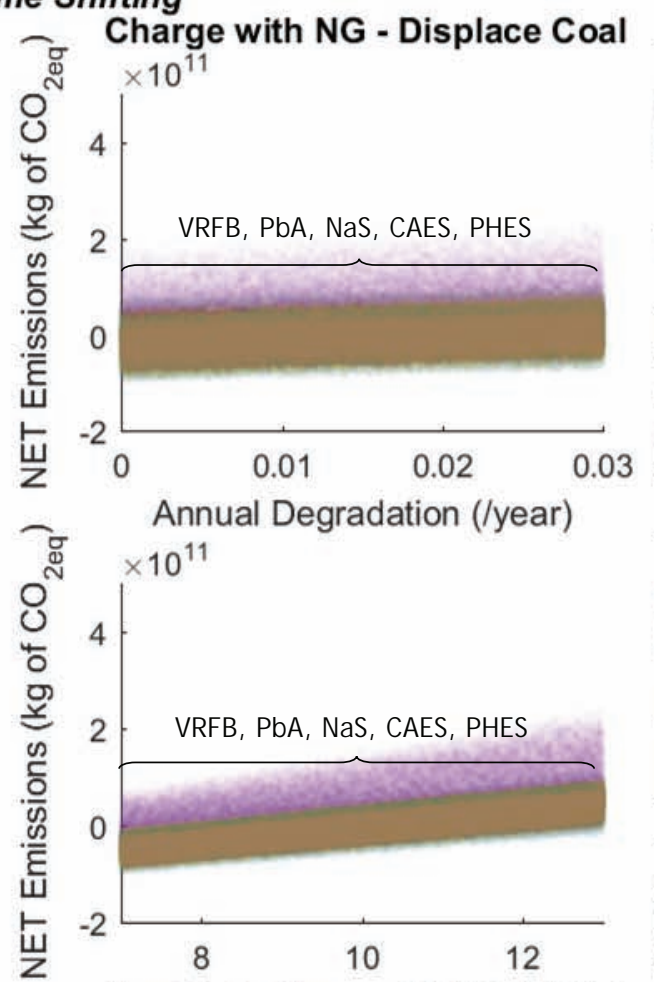

Heat Rate Charge (MMBtu/MWh)

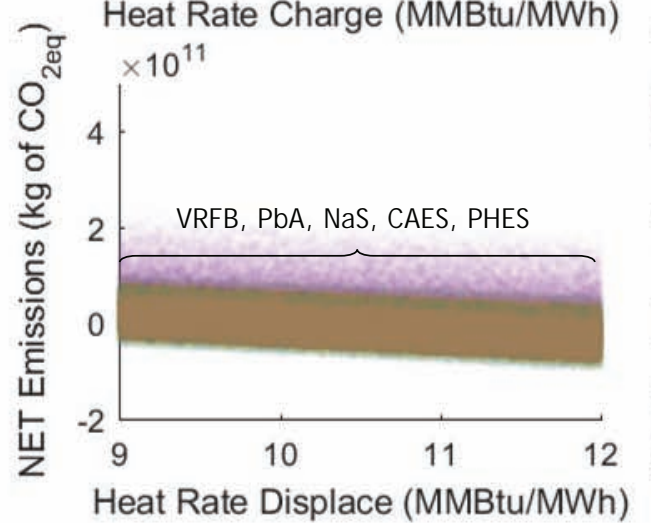

VRFB

$\mathrm{PbA}$

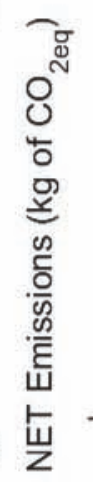

Charge with Coal - Displace NG

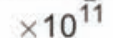

$\times 10$

VRFB, PbA, NaS, CAES, PHES

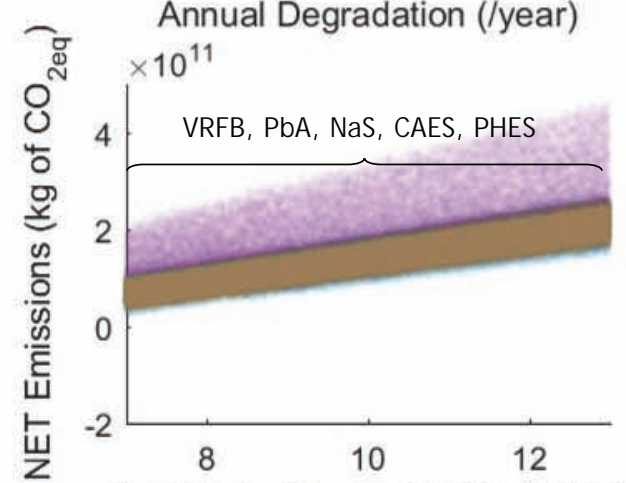

Heat Rate Charge (MMBtu/MWh)

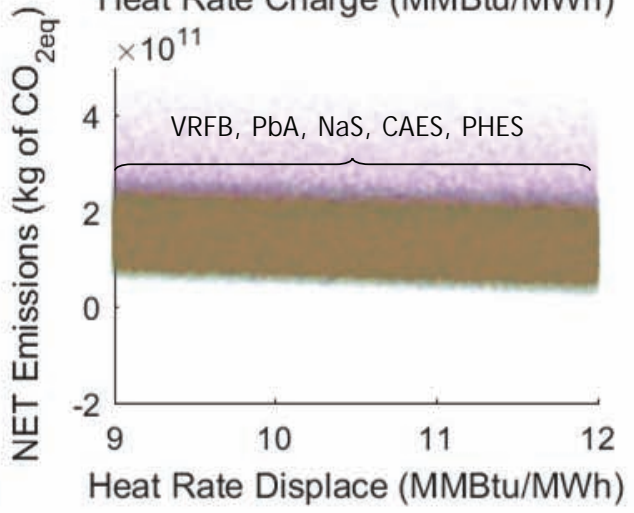

$\mathrm{NaS}$

CAES

PHES

Figure A 1. Impacts on life cycle $\mathrm{CO}_{2 \text { eq }}$ emissions due to assumptions for energy storage round-trip efficiency, energy storage service life, energy storage production burden, annual degradation in energy storage capacity and round-trip efficiency, heat rate of charging technology, and heat rate of displaced technology in time-shifting application (maximum size scenario). Two scenarios are assumed: 1) energy storage is charged with natural gas, and displaces coal based electricity generation (left column), 2) energy storage is charged with coal, and displaces natural gas generation (right column) 

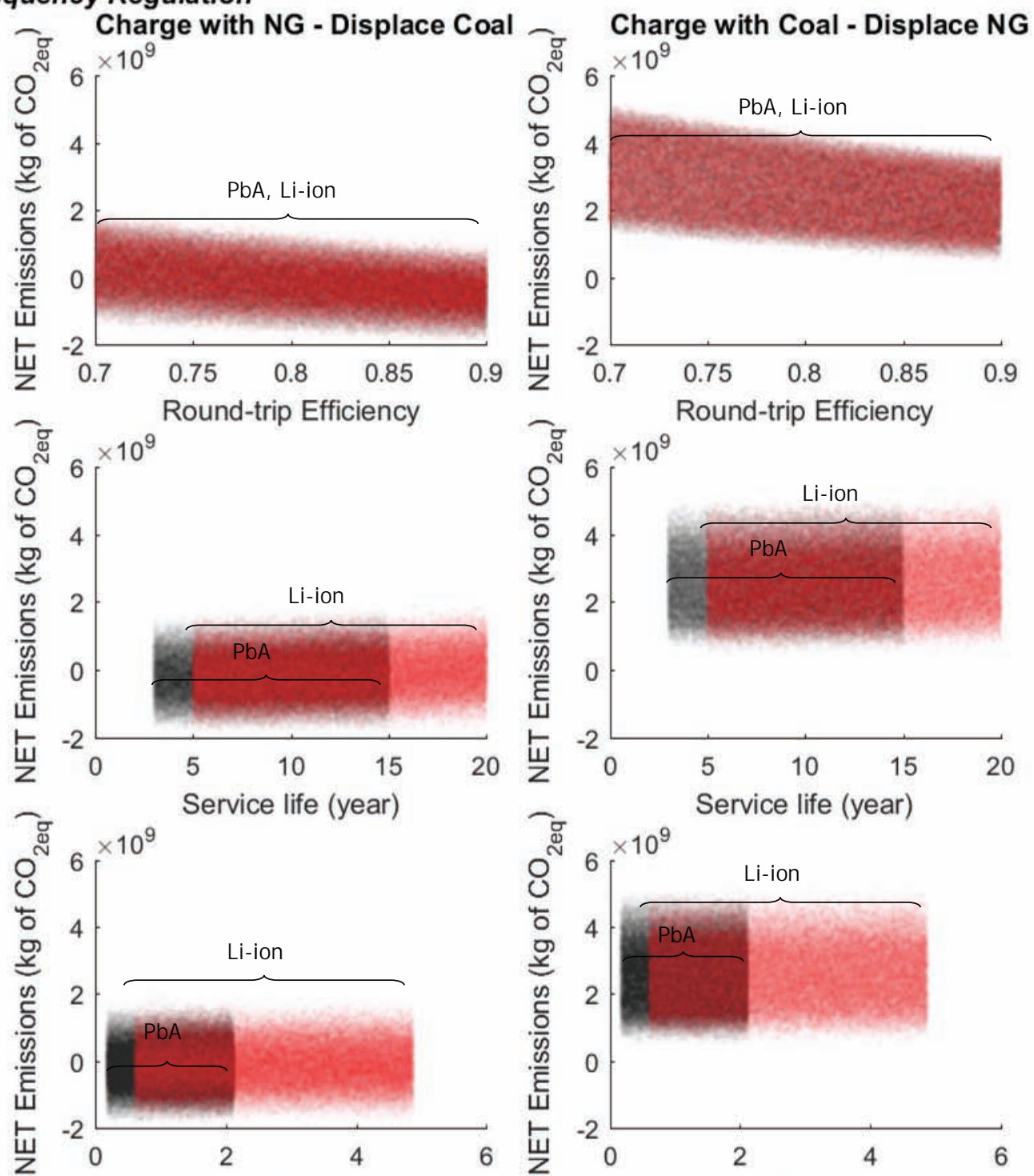

ES Burden $\left(x 10^{5} \mathrm{~kg}\right.$ of $\left.\mathrm{CO}_{2 \mathrm{eq}} / \mathrm{MWh}\right)$

ES Burden $\left(\times 10^{5} \mathrm{~kg}\right.$ of $\left.\mathrm{CO}_{2 \mathrm{eq}} / \mathrm{MWh}\right)$

$0^{\mathrm{PbA}} 0^{\text {Li-ion }}$



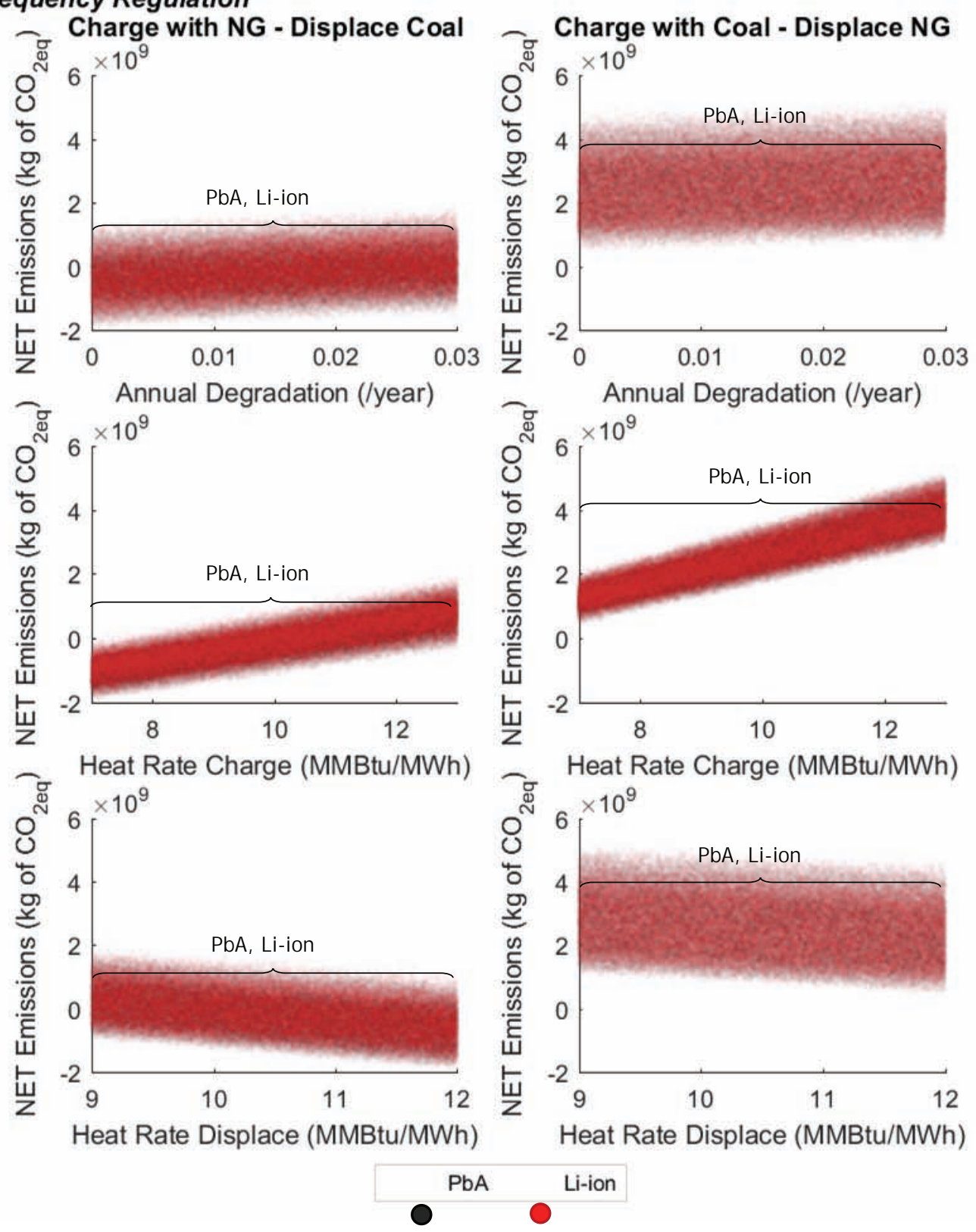

Figure A 2. Impacts on life cycle $\mathrm{CO}_{2 \text { eq }}$ emissions due to assumptions for energy storage round-trip efficiency, energy storage service life, energy storage production burden, annual degradation in energy storage capacity and round-trip efficiency, heat rate of charging technology, and heat rate of displaced technology in Frequency Regulation application (maximum size scenario). Two scenarios are assumed: 1) energy storage is charged with natural gas, and displaces coal based el ectricity generation (left column), 2) energy storage is charged with coal, and displaces natural gas generation (right column) 


\section{Power Reliability}
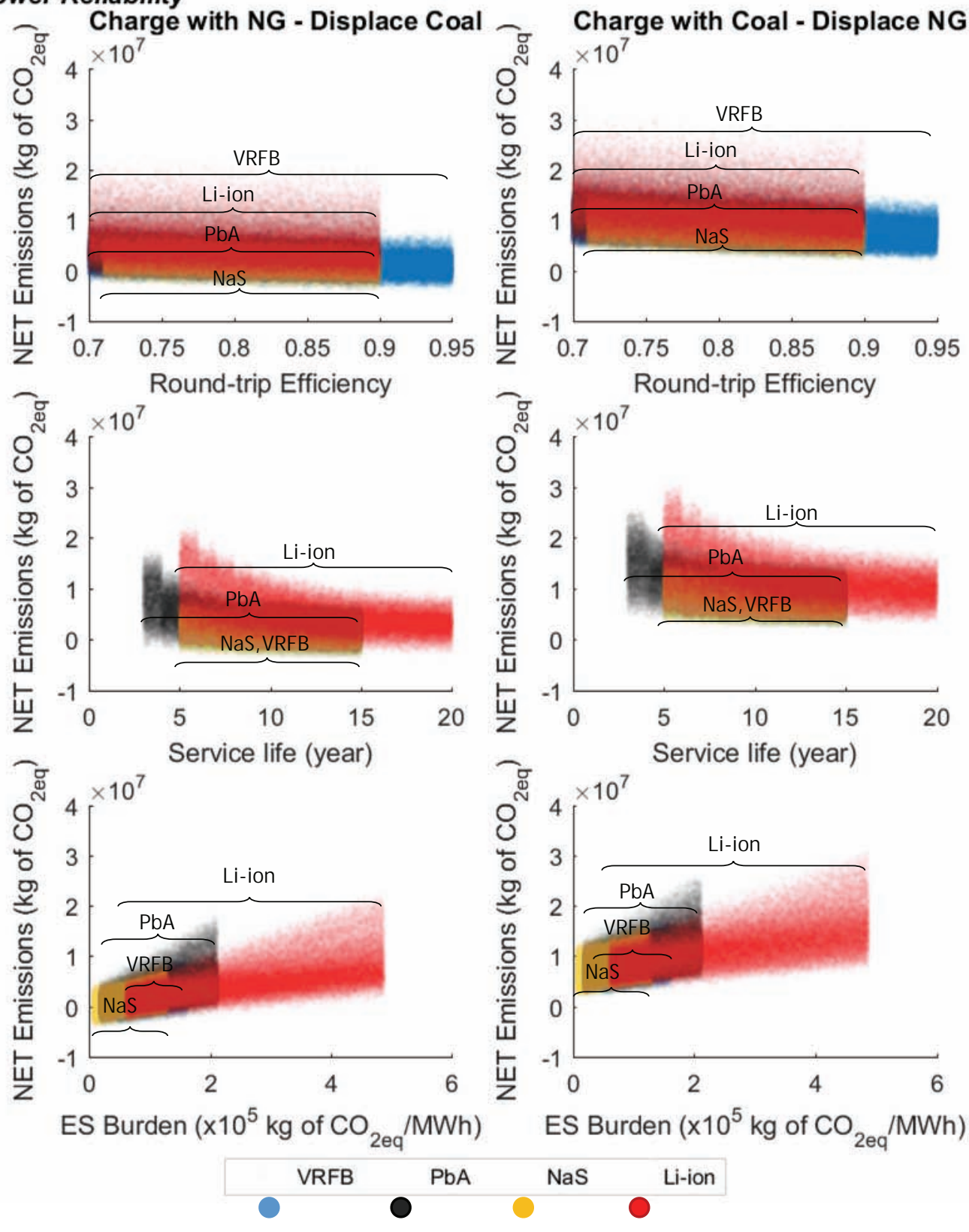


\section{Power Reliability}
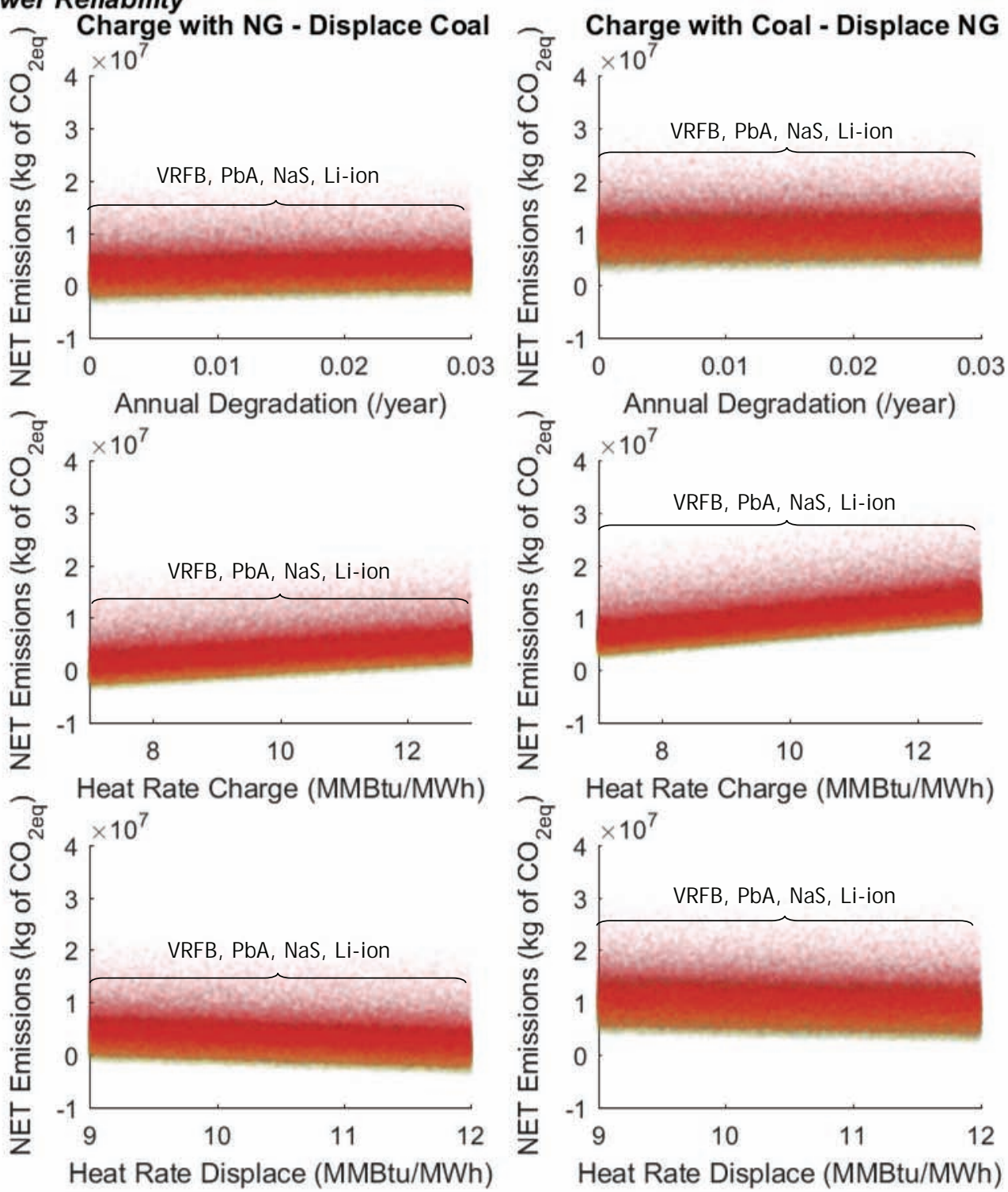

Annual Degradation (/year)

Heat Rate Charge (MMBtu/MWh)
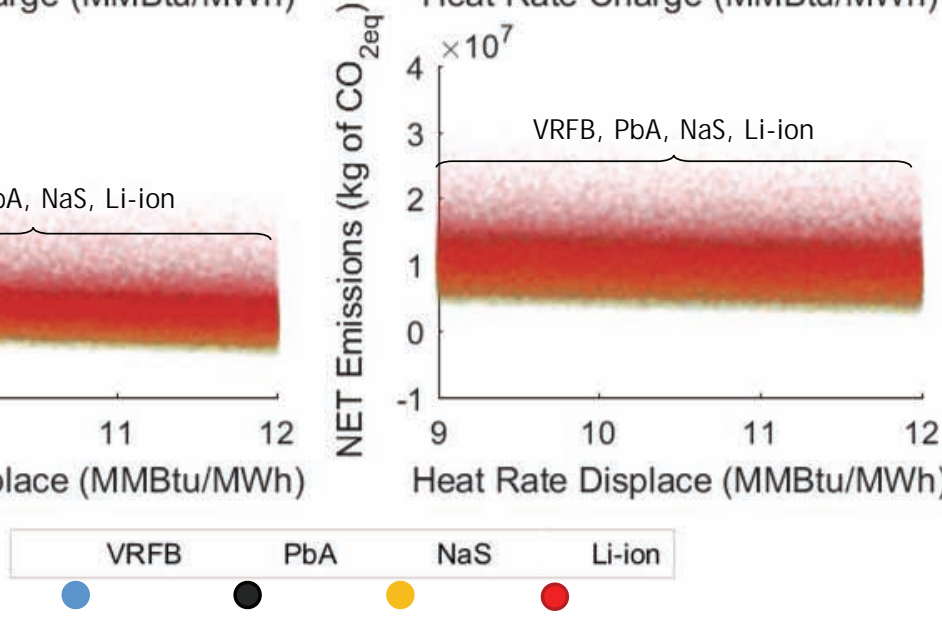

Figure A 3. Impacts on life cycle $\mathrm{CO}_{2 \text { eq }}$ emissions due to assumptions for energy storage round-trip efficiency, energy storage service life, energy storage production burden, annual degradation in energy storage capacity and round-trip efficiency, heat rate of charging technology, and heat rate of displaced technology in power reliability application (maximum size scenario). Two scenarios are assumed: 1) energy storage is charged with natural gas, and displaces coal based electricity generation (left column), 2) energy storage is charged with coal, and displaces natural gas generation (right column)

\section{Appendix B.}

Spider diagrams for net, use-phase, and upstream emissions: 


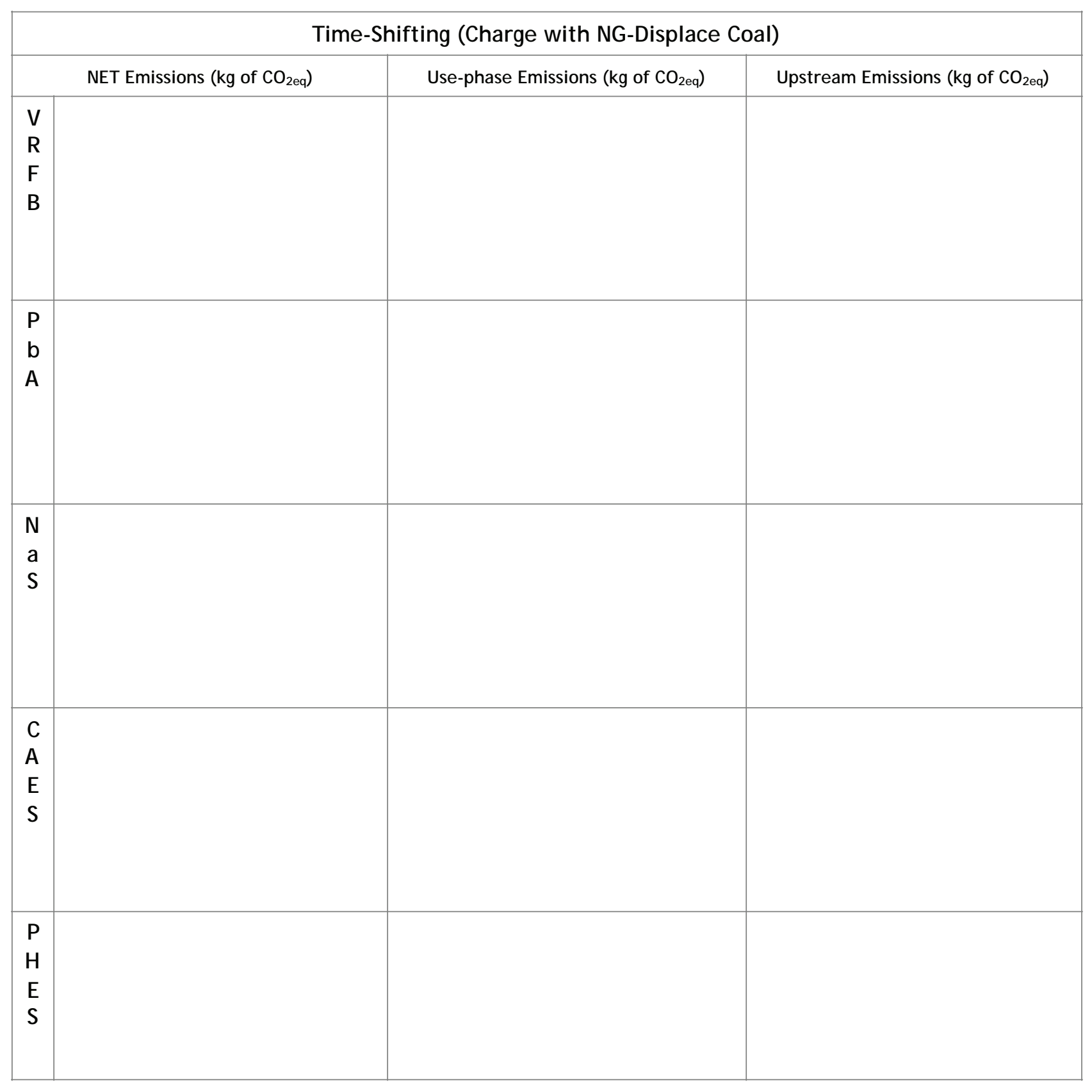

—Round-trip efficiency —Service-life —Degradation — Heat Rate Charge — Heat Rate Displace —ES Burden(kg/MWh)

Figure A 4. Impacts of each parameter on net, use-phase, and upstream emissions in time-shifting application. "ES Burden" stands for energy storage production burden. It is assumed that energy storage is charged with natural gas and displaces coal based electricity generation. $X$-axis represents the minimum, average, and maximum values for each parameter. A ssumptions for values are provided in Tables 2 through 4. (VRFB =vanadium redox flow battery, $\mathrm{PbA}=$ lead-acid battery, $\mathrm{NaS}=$ sodium-sulfur battery, $\mathrm{CAES}=$ compressed air energy storage, $\mathrm{PHES}=$ pumped-hydro energy storage)

\section{Time-Shifting (Charge with Coal-Displace NG)}

NET Emissions ( $\mathrm{kg}$ of $\mathrm{CO}_{2 \mathrm{eq}}$ )

Use-phase Emissions ( $\mathrm{kg}$ of $\mathrm{CO}_{2 \mathrm{eq}}$ )

Upstream Emissions (kg of $\mathrm{CO}_{2 \mathrm{eq}}$ ) 


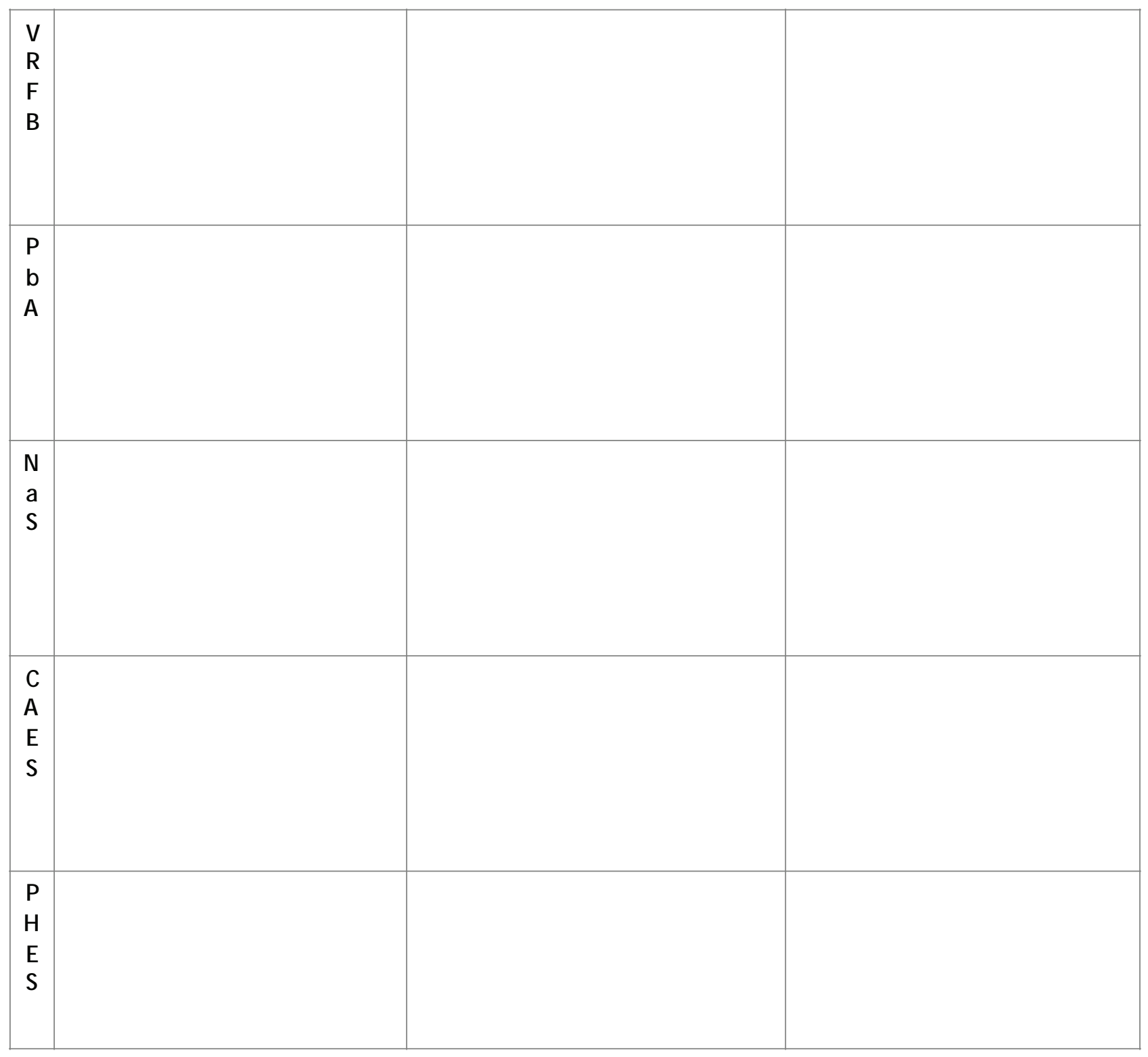

—Round-trip efficiency —Service-life —Degradation — Heat Rate Charge — Heat Rate Displace —ES Burden(kg/MWh)

Figure A 5. Impacts of each parameter on net, use-phase, and upstream emissions in time-shifting application. "ES Burden" stands for energy storage production burden. It is assumed that energy storage is charged with coal based electricity generation and displaces natural gas. $X$-axis represents the minimum, average, and maximum values for each parameter. A ssumptions for values are provided in Tables 2 through 4. (V RFB =vanadium redox flow battery, $\mathrm{PbA}=$ lead-acid battery, $\mathrm{NaS}=$ sodium-sulfur battery, $\mathrm{CAES}=$ compressed air energy storage, $\mathrm{PHES}=$ pumped-hydro energy storage)

\section{Frequency Regulation (Charge with NG-Displace Coal)}




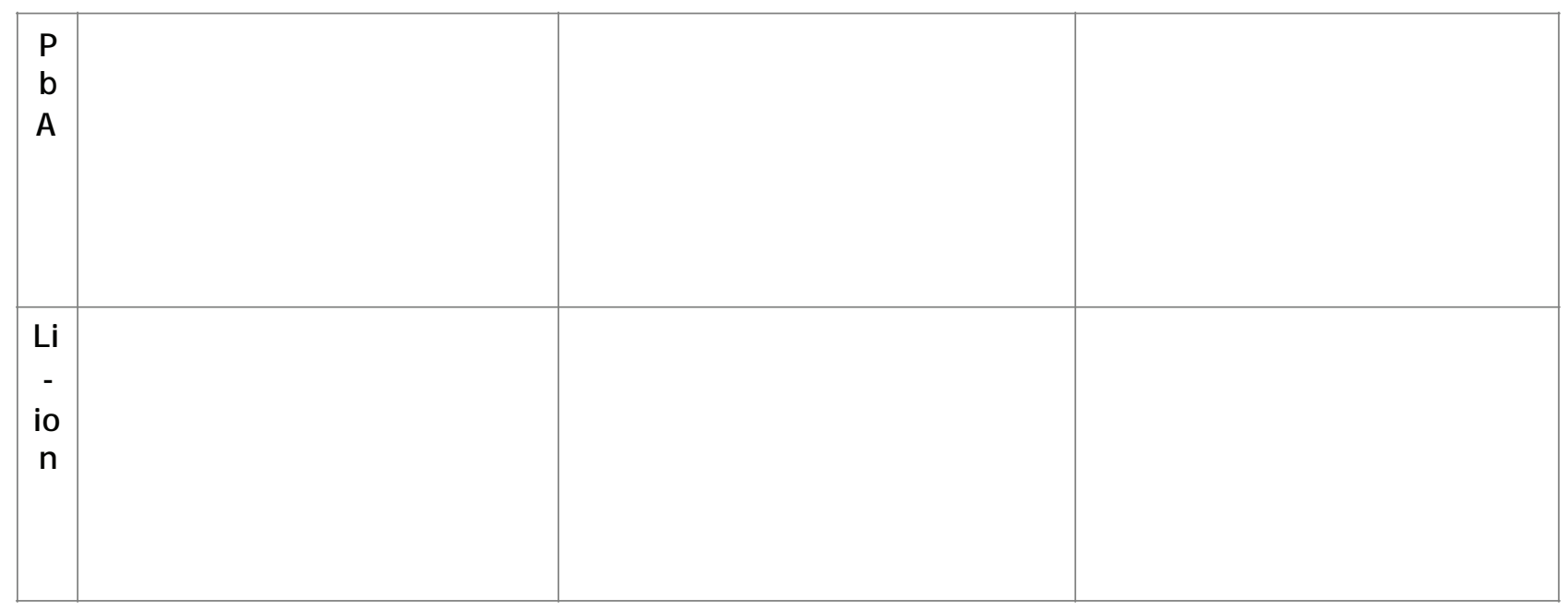

— Round-trip efficiency — Service-life —-Degradation — Heat Rate Charge — Heat Rate Displace — ES Burden(kg/MWh)

Figure A 6. Impacts of each parameter on net, use-phase, and upstream emissions in frequency regulation application. "ES B urden" stands for energy storage production burden. It is assumed that energy storage is charged with natural gas and displaces coal based electricity generation. $X$-axis represents the minimum, average, and maximum values for each parameter. A ssumptions for values are provided in Tables 2 through 4. (PbA = lead-acid battery, Li-ion=lithium-ion battery)

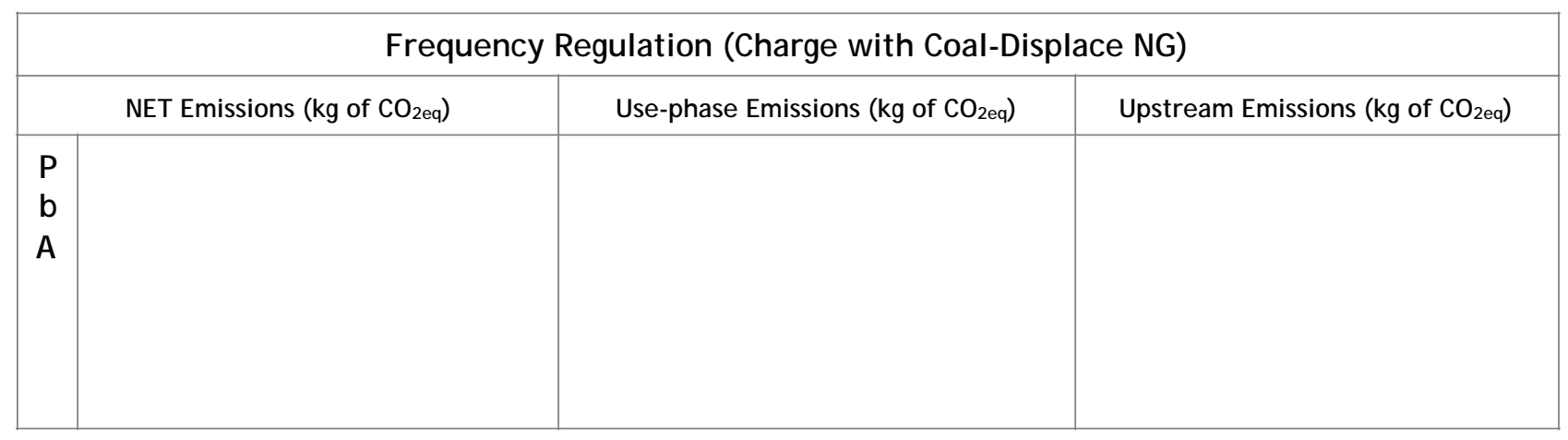




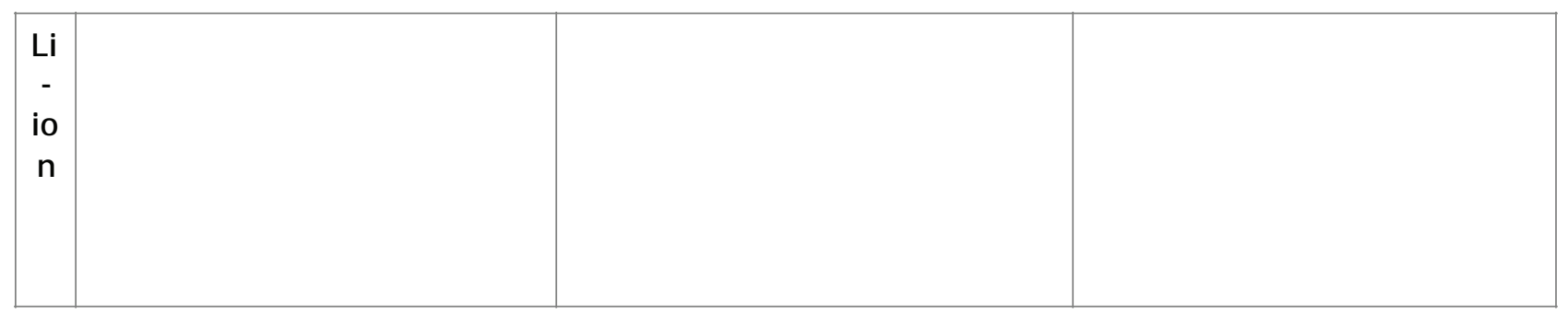

— Round-trip efficiency —Service-life —Degradation — Heat Rate Charge — Heat Rate Displace —ES Burden(kg/MWh)

Figure A 7. Impacts of each parameter on net, use-phase, and upstream emissions in frequency regulation application. "ES B urden" stands for energy storage production burden. It is assumed that energy storage is charged with coal based electricity generation and displaces natural gas. $X$-axis represents the minimum, average, and maximum values for each parameter. A ssumptions for values are provided in Tables 2 through 4. (PbA = lead-acid battery, Li-ion=lithium-ion battery)

\begin{tabular}{|c|c|c|c|}
\hline \multicolumn{4}{|c|}{ Power Reliability (Charge with NG-Displace Coal) } \\
\hline & NET Emissions ( $\mathrm{kg}$ of $\mathrm{CO}_{2 \text { eq }}$ ) & Use-phase Emissions ( $\mathrm{kg}$ of $\mathrm{CO}_{2 \mathrm{eq}}$ ) & Upstream Emissions ( $\mathrm{kg}$ of $\mathrm{CO}_{2 \mathrm{eq}}$ ) \\
\hline $\begin{array}{l}\text { V } \\
\text { R } \\
F \\
\text { B }\end{array}$ & & & \\
\hline
\end{tabular}




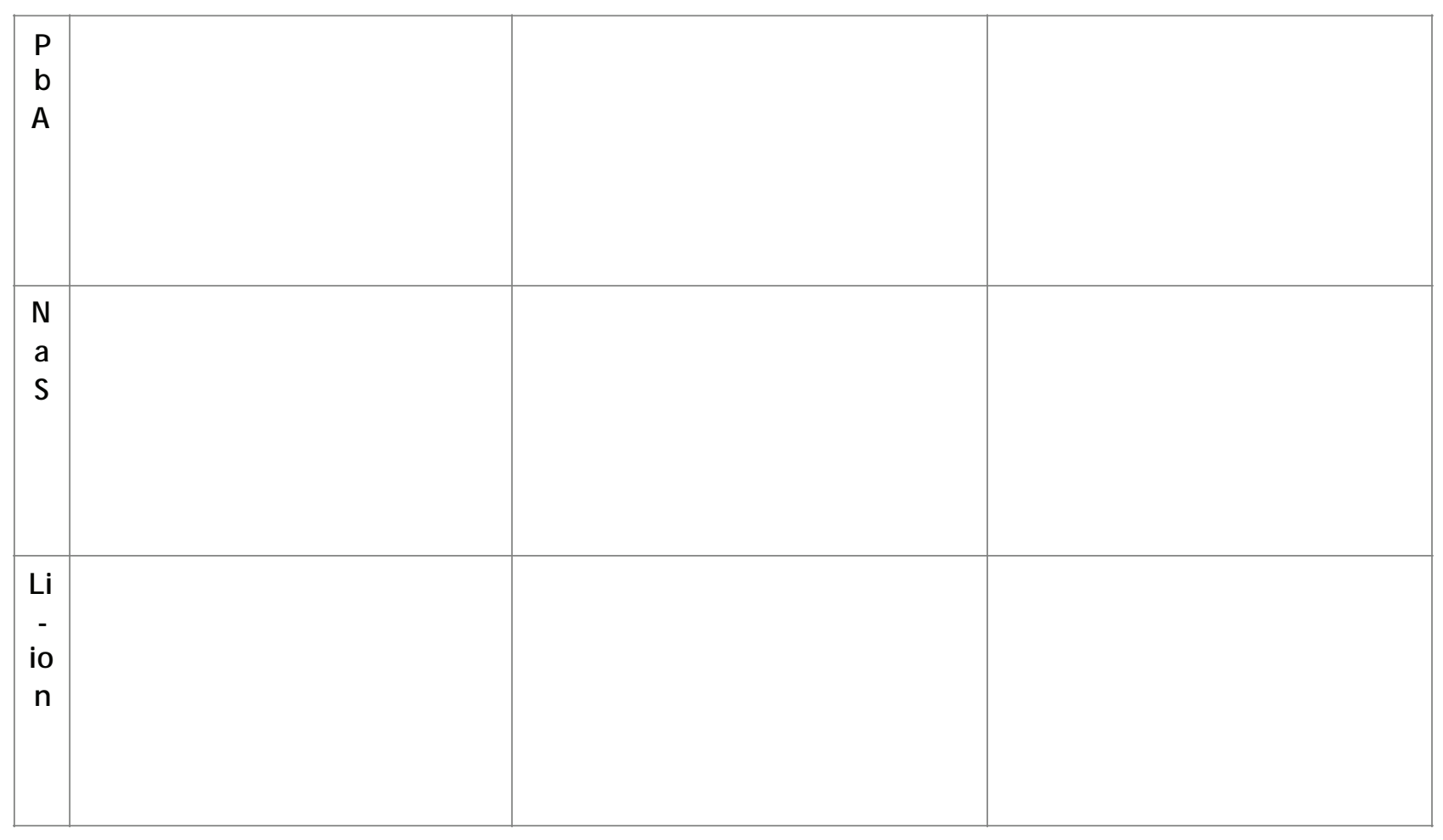

—Round-trip efficiency — Service-life —Degradation — Heat Rate Charge — Heat Rate Displace —ES Burden(kg/MWh)

Figure A 8. Impacts of each parameter on net, use-phase, and upstream emissions in power reliability application. "ES Burden" stands for energy storage production burden. It is assumed that energy storage is charged with natural gas and displaces coal based electricity generation. $X$-axis represents the minimum, average, and maximum values for each parameter. A ssumptions for values are provided in Tables 2 through 4. (V RFB =vanadium redox flow battery, $\mathrm{PbA}=$ lead-acid battery, $\mathrm{NaS}=$ sodium-sulfur battery, Li-ion=lithium-ion battery)

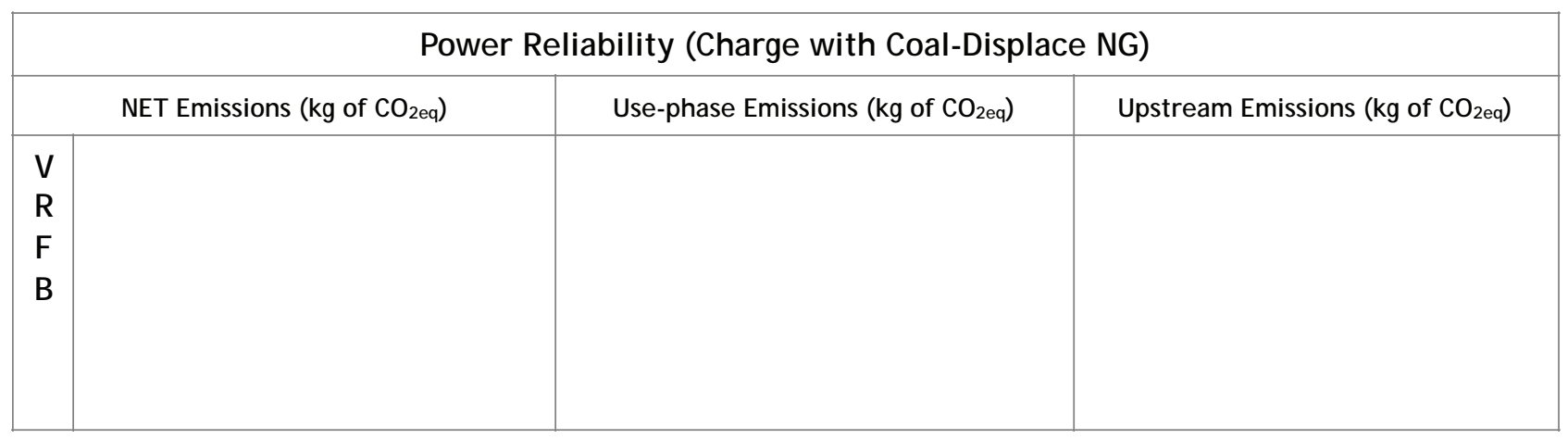




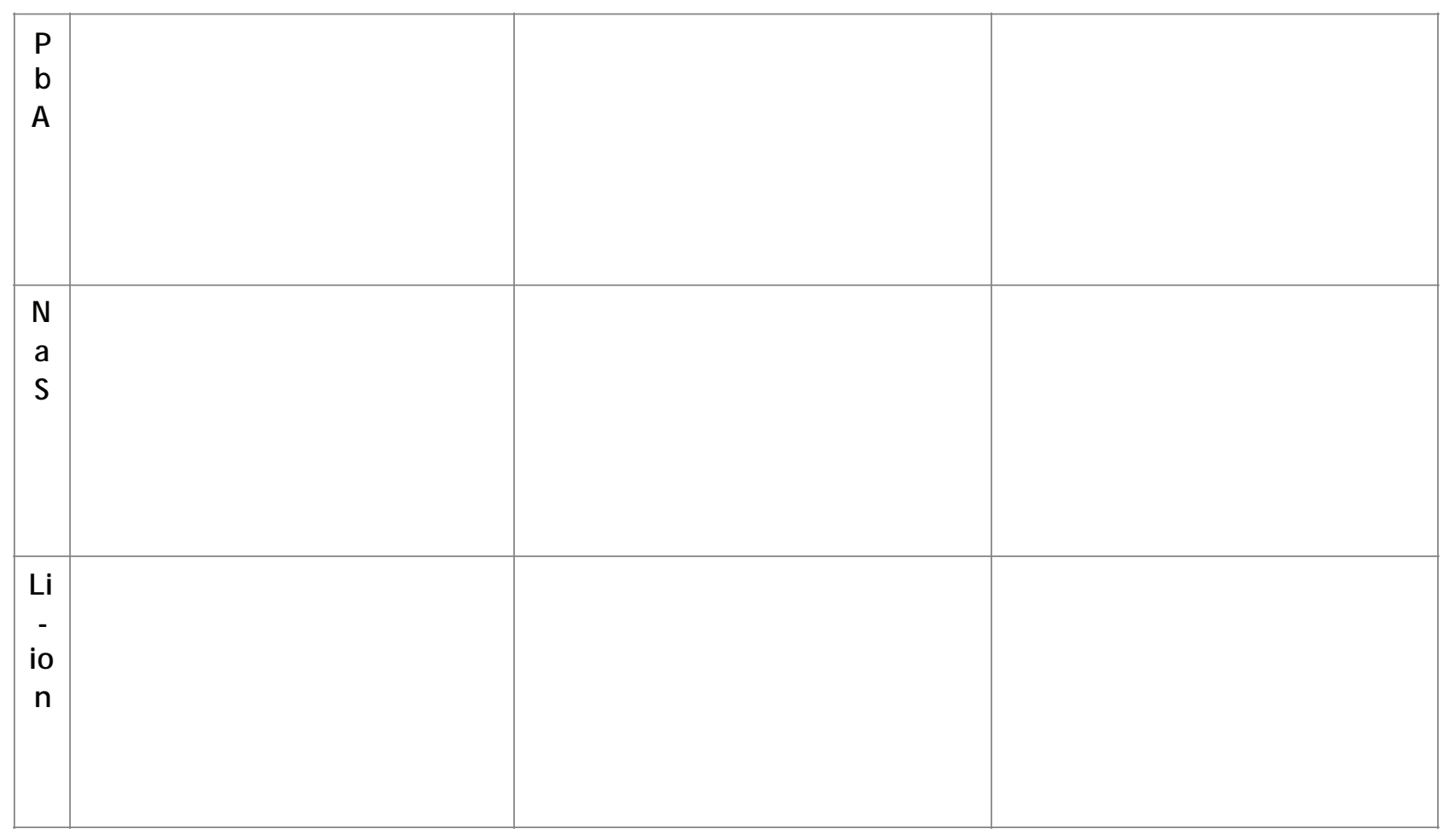

— Round-trip efficiency — Service-life —Degradation — Heat Rate Charge — Heat Rate Displace — ES Burden(kg/MWh)

Figure A 9. Impacts of each parameter on net, use-phase, and upstream emissions in power reliability application. "ES Burden" stands for energy storage production burden. It is assumed that energy storage is charged with coal based electricity generation and displaces natural gas. $X$-axis represents the minimum, average, and maximum values for each parameter. A ssumptions for values are provided in Tables 2 through 4. (VRFB =vanadium redox flow battery, $\mathrm{PbA}=$ lead-acid battery, $\mathrm{NaS}=$ sodium-sulfur battery, Li-ion= lithium-ion battery)

\section{Appendix C.}

List of tw elve principles for green energy storage systems in grid applications:

1. Charge clean and displace dirty.

2. Energy storage should have lower environmental impact than displaced infrastructure.

3. M atch application to storage capabilities to prevent degradation.

4. Avoid oversizing energy storage systems. 
5. M aintain to limit degradation.

6. Design and operate energy storage for optimal service life,

7. Design and operate energy storage with maximum round-trip efficiency.

8. Minimize consumptive use of non-renewable materials.

9. M inimize use of critical materials.

10. Substitute non-toxic and non-hazardous materials.

11. M inimize the environmental impact per unit of energy service for material production and processing.

12. Design for end-of-life.

\section{References}

[1] Lin, Y.; J ohnson, X. J., M athieu, J. L. Emissions impacts of using energy storage for power system reserves. Applied Energy. 2016, 16, 444-456; D OI 10.1016/j.apenergy.2016.01.061.

[2] A rbabzadeh, M .; J ohnson, J.X .; K eoleian, G.A .; Rasmussen, P.G.; Thompson, L.T. Twelve principles for green energy storage in grid applications. Environmental Science \& Technology. 2015 50 (2), 1046-1055, DOI 10.1021/acs.est.5b03867.

[3] Sanfelix, J.; M essagie, M .; O mar, N.; M ierlo, J . V.; Hennige, V. "Environmental performance of advanced hybrid energy storage systems for electric vehicle applications," Applied Energy. 2015. $137,925-930$.

[4] Peters, J. F.; B aumann, M .; Zimmermann, B .; B raun, J .; Weil, M. "The environmental impact of Li-ion batteries and the role of key parameters," Renewable and Sustainable Energy Reviews. 2017. $67,491-506$.

[5] A Review of Battery Life-cycle Analysis: State of Knowledge and Critical Needs; A NL/ESD/ 10-7; A rgonne N ational Laboratory: A rgonne, IL, USA, 2010, https://greet.es.anl.gov/publicationbatteries Ica. 
[6] Chul Kim, H.; Wallington, J. T.; A rsenault, R.; B ae, C., A hn, S., Lee, J. Cradle-to-gate emissions from a commercial electric vehicle Li-ion battery: A comparative analysis. Environmental Science \& Technology. 2016, DOI 10.1021/acs.est.6b00830.

[7] Bossche, P.; Vergels, F.; Van M ierlo, J.; M atheys, J.; Van A utenboer, W. SU B AT: A $n$ assessment of sustainable battery technology. J ournal of Power Sources. 2005, 162 (2), 913-919; D OI 0.1016/ j.jpowsour.2005.07.039.

[8] Hou, Y.; Vidu, R.; Stroeve, P. Solar energy storage methods. Industrial \& Engineering Chemistry Research. 2011 50, 8954-8964; D OI 10.1021/ie2003413.

[9] L archer, D.; Tarascon, J-M . Towards greener and more sustainable batteries for electrical energy storage. Nature Chemistry. 2015, 7(1), 19-29; DOI 10.1038/nchem.2085.

[10] B ouman, E.; O berg, M .; Hertwich, E. L ife cycle assessment pf compressed air energy storage (CAES). The 6th International Conference on Life Cycle M anagement in G othenburg. 2013.

[11] A rbabzadeh, M .; J ohnson, J .X .; De K leine, R.; K eoleian, G.A . Vanadium redox flow batteries to reach GHG emissions targets in an off-grid configuration. Applied Energy. 2015, 146, 397-408; D OI 10.1016/j.apenergy.2015.02.005.

[12] Hiremath, M .; Derendorf, Karen; Vogt, T. Comparative life cycle assessment of battery storage systems for stationary applications. Environmental Science \& Technology. 2015, 49 (8), 4825-4833; DOI 10.1021/es504572q.

[13] Poizot, Ph.; Dolhem, F. Clean energy new deal for a sustainable world: from non- $\mathrm{CO}_{2}$ generating energy sources to greener electrochemical storage devices. Energy \& Environmental Science. 2011, 4 (6), 2003-2019; DOI 10.1039/C OEE 00731E.

[14] Oliveira, L.; M essagie, M.; M ertens, J.; Laget, H.; Coosemans, T.; Van M ierlo, J. Environmental performance of electricity storage systems for grid applications, a life cycle approach. Energy Conversion and Management. 2015, 101, 326-335; D OI 10.1016/j.enconman. 2015.05.063.

[15] Fisher, M . J.; A pt, J. "Emissions and economics of behind-the-meter electricity storage," Environmental Science \& Technology. 2016. D0I: 10.1021/acs.est.6b03536. 
[16] Denholm, P. Improving the technical, environmental and social performance of wind energy systems using biomass-based energy storage. Renewable Energy. 2006, 31 (9), 1355-1370; D O I 10.1016/j.renene.2005.07.001.

[17] Denholm, P.; K ulcinski, G. Life cycle energy requirements and greenhouse gas emissions from large scale energy storage systems. Energy Conversion and M anagement. 2004, 45(13-14), 2153-2172; DOI 10.1016/j.enconman.2003.10.014.

[18] Pettinger, K. H.; Dong, W. "W hen does the operation of a battery become environmentally positive?" J ournal of Electrochemical Society. 2017. 164 (1), A 6274-A 6277.

[19] Carson, R. T.; N ovan, K. The private and social economics of bulk electricity storage. J ournal of Environmental Economics and M anagement. 2013, 66 (3), 404-423; DOI 10.1016/j.jeem. 2013.06.002.

[20] Hadjipaschal is, I.; Poullikkas, A.; Efthimiou, V. Overview of current and future energy storage technologies for electric power applications. Renewable and Sustainable Energy Reviews. 2009, 13 (6-7), 1513-1522; DOI 10.1016/j.rser.2008.09.028.

[21] Schaber, Ch.; M azza, P.; Hammerschlag, R. U tility-scale storage of renewable energy. The Electricity J ournal. 2004, 17(6), 21-29; DOI 10.1016/j.tej.2004.05.005.

[22] Evans, A.; Strezov, V.; Evans, T. A ssessment of utility energy storage options for increased renewable energy penetration. Renewable and Sustainable Energy Reviews. 201216 (6), 4141-4147; D OI 10.1016/j.rser.2012.03.048.

[23] Energy Storage for Power Systems A pplications: A Regional A ssessment for N orthwest Power Pool (N W PP); Pacific N orthwest National Laboratory: Richland, WA, USA, 2010.

[24] Diouf, B.; Pode, R. "Potential of lithium-ion batteries in renewable energy," Renewable Energy. 2015 76, 375-380.

[25] Electricity Energy Storage O ptions, A white paper on applications, costs, and benefits; EPRI 1020676; Electric Power Research Institute: Palo A Ito, CA , USA , 2010; http://large.stanford.edu/ courses/2012/ph240/doshay1/docs/EPRI.pdf. 
[26] Zhao, H.; Wu, Q.; Hu, S.; Xu, H.; Rasmussen, C. N. "Review of energy storage system for wind power integration support," Applied Energy. 2015. 137, 545-553.

[27] G rid Energy Storage; U.S. Department of Energy: Washington, DC, USA, 2013; http:/l www.sandia.gov/ess/docs/other/Grid_Energy_Storage_Dec 2013.pdf.

[28] E nergy Storage for Electricity G rid: Benefits and M arket Potential Assessment; SA N D2010-0815; Sandia National L aboratory: Livermore, CA , USA, 2010; http:/l www.sandia.gov/ess/publications/SA N D2010-0815.pdf.

[29] Market and Policy Barriers to E nergy Storage D eployment; SA ND2013-7606; Sandia National Laboratory: Livermore, CA, USA, 2013;

http://www.sandia.gov/ess/publications/SA ND2013-7606.pdf.

[30] D OE/EPRI 2013 Electricity Storage Handbook in Collaboration with NRECA; SA N D2013-5131; Sandia National L aboratory: Livermore, CA, USA, 2013; http:// www.sandia.gov/ess/publications/SA N D 2013-5131.pdf.

[31] Evaluating U tility Procured Electric Energy Storage Resources: A Perspective for State Electric U tility Regulators; SA N D2012-9422; Sandia National L aboratory: Livermore, CA, USA, 2012; http://www.sandia.gov/ess/publications/SA N D 2012-9422.pdf.

[32] E nergy Storage for G rid Connected Wind Generation Applications; EPRI 1008703; Electric Power Research Institute: Palo A Ito, CA, USA, 2004;

http://www.sandia.gov/ess/publications/EPRI-D OE\%20ESHB \%20W ind\%20Supplement.pdf.

[33] Chen, H.; Cong, T.; Yang, W.; Tan, Ch.; Li, Y.; Ding, Y. Progress in electrical energy storage system: A critical review. Progress in Natural Science. 2009, 19 (3), 291-312; D 01 10.1016/j.pnsc. 2008.07.014.

[34] Rahman, F.; Rehman, S; A bdul-M ajeed, M. Overview of energy storage systems for storing electricity from renewable energy sources in Saudi A rabia. Renewable and Sustainable Energy Reviews. 201216 (1), 274-283; D OI 10.1016/j.rser.2011.07.153. 
[35] I brahim, H.; Ilinca, A .; Perron, J . E nergy storage systems-Characteristics and comparisons.

Renewable and Sustainable Energy Reviews. 2008, 12 (5), 1221-1250; DOI 10.1016/j.rser. 2007.01.023.

[36] The Role of Energy Storage with Renewable Electricity Generation; NREL NREL/ TP-6A 2-47187; National Renewable Energy Laboratory: B oulder, CO, USA , 2010; http:// www.nrel.gov/docs/fy10osti/47187.pdf.

[37] Divya, K.C.; Ostergaard, J. B attery energy storage technology for power systems-A n overview. Electric Power Systems Research. 2008, 79, 511-520; DOI 10.1016/j.epsr.2008.09.017.

[38] Pickard, W. F.; Shen, A. Q .; Hansing, N. J. Parking the power: Strategies and physical limitations for bulk energy storage in supply-demand matching on a grid whose input power is provided by intermittent sources. Renewable and Sustainable Energy Reviews. 2009, 13 (8), 1934-1945; DOI 10.1016/j.rser.2009.03.002.

[39] Hittinger, E.; W hitacre, J. F., A pt, J. W hat properties of grid energy storage are most val uable? J ournal of P ower Sources. 2012 206, 436-449; DOI 10.1016/j.jpowsour.2011.12.003.

[40] Luo, X.; Wang, J.; Dooner, M.; Clarke, J.; Overview of current development in electrical energy storage technologies and the application potential in power system operation. Applied Energy. 2015. 137, 511-536, DOI 10.1109/CPE.2009.5156019.

[41] F requency Regulation Basics and Trends; OR NL/TM -2004/291; Oak Ridge National Laboratory: Oak Ridge, TN, USA, 2004;

[42] Castillo, A .; Gayme, D. F. Grid-scale energy storage applications in renewable energy integration: A survey. Energy Conversion and M anagement. 2014, 87, 885-894, D OI 10.1016/ j.enconman.2014.07.063.

[43] K ousksou, T.; B ruel, P.; J amil, A .; Rhafiki, T. E.; Zeraouli, Y. Energy storage: A pplications and challenges. Solar Energy M aterials \& Solar Cells. 2014, 120, 59-80, D OI 10.1016/j.solmat. 2013.08.015.

[44] Świerczyński, M .; Stroe, D. I.; Stan, A .-I.; Teodorescu, R.; Sauer, D. U. Selection and Performance-Degradation M odeling of LiM 02 /Li4 Ti5 012 and LiF ePO 4 /C Battery Cells as 
Suitable Energy Storage Systems for Grid Integration With Wind Power Plants: A n Example for the Primary Frequency Regulation Service. IEEE Transactions on Sustainable Energy. 2014, 5 (1), 90-101, DOI 10.1109/TSTE.2013.2273989.

[45] Rodrigues, E.; Osorio, G.; Godina, R.; B izuayehu, A .; Lujano-R ojas, J.; M atias, J.; Catalao, J. M odelling and sizing of $\mathrm{NaS}$ (sodium sulfur) battery energy storage system for extending wind power performance in Crete Island. Energy. 2015, 90, 1606-1617, D OI 10.1016/j.energy. 2015.06.116.

[46] Wen, Z.; Cao, J.; Gu, Z.; X u, X.; Zhang, F.; Lin, Z. Research on sodium sulfur battery for energy storage. Solid State Ionics. 2008, 179 (27-32), 1697-1701, DOI

[47] B attke, B.; Schmidt, T.S.; G rosspietsch, D.; H offmann, V. H. A review and probabilistic model of life cycle costs of stationary batteries in multiple applications. Renewable and Sustainable Energy Reviews. 2013, 25, 240-250; DOI 10.1016/j.rser.2013.04.023.

[48] Sullivan, J.L.; Gaines, L. Status of life cycle inventories for batteries. Energy Conversion and M anagement. 2012, 58, 134-148; DOI 10.1016/j.enconman.2012.01.001.

[49] Spanos, C.; Turney, D.E .; Fthenakis, V. Life-cycle analysis of flow-assisted nickel zinc-, manganese dioxide-, and valve-regulated lead-acid batteries designed for demand-charge reduction. Renewable and Sustainable Energy Reviews. 2015. 43, 478-494. DOI 10.1016/j.rser.2014.10.072.

[50] Hueso, K. B .; A rmand, M .; R ojo, T. High temperature sodium batteries: status, challenges and future trends. Energy \& Environmental Science. 2013, 6, 734-749, DOI 10.1039/C3EE24086] .

[51] Richa, K .; B abbitt, C.; N enadic, N .; Gaustad, G. Environmental trade-offs across cascading lithium-ion battery life cycles. The International J ournal of Life Cycle Assessment. 2012 1-16; D O 10.1007/s11367-015-0942-3.

[52] A hmadi, L.; Fowler, M.; Y oung, S. B .; Fraser, R. A .; G affney, B .; Walker, S. B. Energy efficiency of Li-ion battery packs re-used stationary power application. Sustainable Energy Technologies and Assessments. 2014 8, 9-17; D OI 10.1016/j.seta.2014.06.006. 
[53] Advanced models and controls for prediction and extension of battery lifetime; NREL/ PR-5400-61037; National Renewable Energy L aboratory: Denver, CO, USA , 2014; http:/l www.nrel.gov/docs/fy140sti/61037.pdf.

[54] B olund, B .; B ernhoff, H.; L eijon, M . Flywheel energy and power storage systems. Renewable and Sustainable Energy Reviews. 2007. 11 (2), 235-258; D 0I 10.1016/j.rser.2005.01.004.

[55] Chen, H.; Zhang, X.; Liu, J.; Tan, Ch. Energy storage-Technologies and applications. 2013.

[56] Advanced redox flow batteries for stationary electrical energy storage; PN NL -21174; Pacific N orthwest National L aboratory: Richland, WA, USA, 2012; http://www.pnnl.gov/main/ publications/external/technical_reports/PN NL-21174.pdf.

[57] Ellingsen, L.; M ajeau-B ettez, G .; Singh, B.; Srivastava, A . K .; Valøen, L. O.; Strømman, A . H. Life Cycle A ssessment of a Lithium-I on B attery Vehicle Pack. J ournal of Industrial E cology. 2013, 18 (1), DOI 10.1111/jiec.12072.

[58] M cM anus, M. Environmental consequences of the use of batteries in low carbon systems: The impact of battery production. Applied Energy. 2012, 93, 286-295; D OI 10.1016/j.apenergy. 2011.12.062.

[59] Zackrisson, M .; Avellán, L.; Orlenius, J. L ife cycle assessment of lithium-ion batteries for plug-in hybrid electric vehicles-Critical issues. J ournal of Cleaner Production. 2010, 18, 1519-1529, DOI 10.1016/j.procir.2015.02.185.

[60] M ajeau-B ettez, G.; Hawkins, T. R.; Strømman, A . H. Life Cycle Environmental A ssessment of Lithium-I on and Nickel M etal Hydride Batteries for Plug-In Hybrid and B attery Electric Vehicles. Environmental Science \& Technology. 2011 45 (10), 4548-4554, DOI 10.1021/es103607c.

[61] Dunn, J. B.; Gaines, L.; K elly, J. C.; James, C.; Gallagher, K. G. The significance of Li-ion batteries in electric vehicle life-cycle energy and emissions and recycling's role in its reduction. Energy \& Environmental Science. 2015, 8, 158-168, D OI 10.1039/c4ee03029j.

[62] Dunn, J. B.; Gaines, L.; Sullivan, J.; Wang, M. Q. Impact of recycling on cradle-to-gate energy consumption and greenhouse gas emissions of automotive lithium-ion batteries. Environmental Science \& Technology. 2012, 46, 12704-12710, DOI 10.1021/es302420z. 
[63] A rgonne N ational L aboratory Greet M odel, 2016 release;

\section{https://greet.es.anl.gov/.}

[64] Emissions Factor for greenhouse gas inventories; http://www.epa.gov/climateleadership/ documents/emission-factors.pdf.

[65] 2015 ElA form 923-A nnual Electric Utility Data; http://www.eia.gov/electricity/data/eia923/.

[66] Helton, J. C.; Davis, F. J. Latin hypercube sampling and the propagation of uncertainty in analyses of complex systems. Reliability Engineering \& System Safety. 2003, 81 (1), 23-69, D O 10.1016/S0951-8320(03)00058-9.

[67] Burnham, A.; Han, J .; Clark, C.; Wang, M.; Dunn, J.; Palou-Rivera, I. L ife-cycle greenhouse gas emissions of shale gas, natural gas, coal, and petroleum. Environmental Science \& Technology. 201246 (2), 619-627; D OI 10.1021/es201942m

[68] Weber, C. L.; Clavin, C. Life cycle carbon footprint of shale gas: Review of evidence and implications. Environmental Science \& Technology. 2012,46 (11), 5688-5695, DOI 10.1021/ es300375n.

[69] A brahams, L. S.; Samaras, C; Griffin, W. M.; M atthews, H. S. Life cycle greenhouse gas emissions from U.S. liquefied natural gas exports: Implications for end uses. Environmental Science \& Technology. 2015, 49 (5), 3237-3245, DOI 10.1021/es505617p.

[70] Howarth, R. W. A bridge to now here: methane emissions and the greenhouse gas footprint of natural gas. Energy Science \& Engineering. 2014, 2 (2), 10.1002/ese3.35.

[71] O'D onoughue, P. R.; Heath, G. A.; Dolan, S. L.; Vorum, M. Life cycle greenhouse gas emissions of electricity generated from conventionally produced natural gas. J ournal of Industrial E cology. 2014, 18 (1), 23-69, D OI 10.1111/jiec.12084. 